\title{
THE SOUTH PACIFIC COMMISSION
}

\section{FISHERIES \\ NEWSLETER}

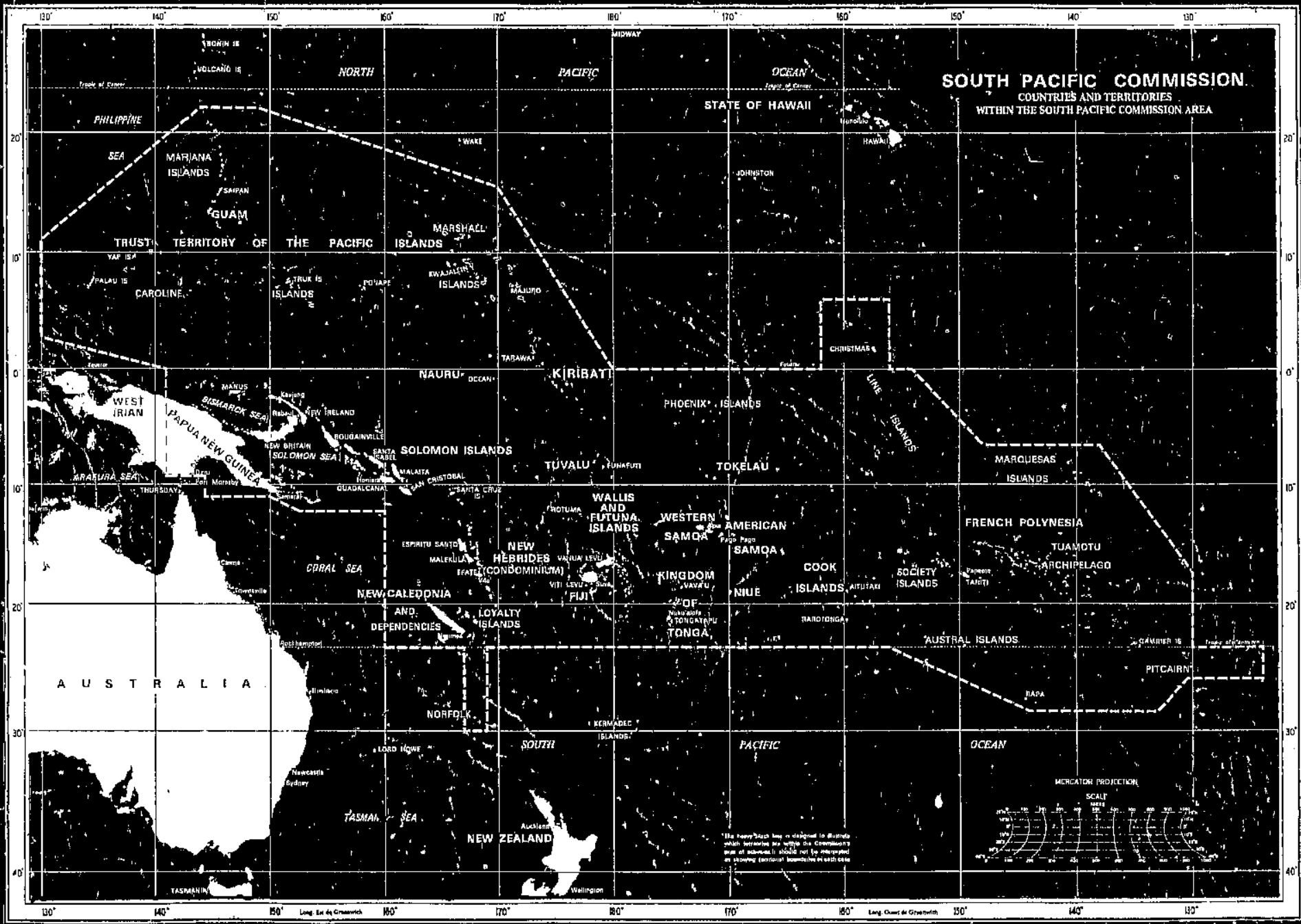

No. 23

June 1982

South Pacific Commission

B.P. D5, Noumea Cedex

New Caledonia 


\section{THE SOUTH PACIFIC COMMISSION FISHERIES NEWSLETTER}

\section{Editors:}

B.R. Smith (Fisheries Adviser) and

M.T. Gentle (Assistant Fisheries Officer)

South Pacific Commission

P.O. Box D5, Noumea Cedex,

New Caledonia

\section{CONTENTS}

Smail-scale pole-and-line skipjack fishery in Western Samoa: report on preliminary trials

by D.M. Popper and A.L. Philipp ....... 1

Hawaiian 'akule' night fishing gear

by R. Powell ............... 8

Fiji Fisheries Division's boat-building and rural training scheme

by M.T. Gentle ............... 14

Deepwater shrimps in Tonga $\ldots \ldots \ldots \ldots \ldots \ldots \ldots \ldots \ldots \ldots \ldots \ldots$

Sea turtles: a shared resource of the Pacific Islands

by G.H. Balazs ................ 22

Should we return to sail?

by 0. Gulbrandsen ............. 25

Recent South Pacific Commission fisheries publications $\ldots \ldots \ldots \ldots \ldots \ldots 27$ 


\title{
SMALL-SCALE POLE-AND-LINE SKIPJACK FISHERY IN WESTERN SAMOA: REPORT ON PRELIMINARY TRIALS ${ }^{1}$
}

\author{
D.M. Popper ${ }^{2}$ and A.L. Philipp \\ Fisheries Division, Department of Economic Development \\ P.O. Box 295, Apia, Western Samoa
}

Four major constraints hinder the development of pole-and-line skipjack fisheries in small Pacific Island countries. These are:

(1) Shortage of live bait,

(2) The high cost and sophistication of the boats and equipment used for this type of fishery,

(3) The rising cost of fuel used in long searches for schools,

(4) The reluctance of local fishermen to make prolonged offshore fishing trips.

Results of recent developments in Western Samoa may alleviate these problems: success in the culture of top-minnows (Poecilia mexicana) is a step toward solving the bait shortage, utilisation of small, locally built catamarans eliminates the costly and sophisticated large vessels, and deployment of fish aggregation devices (FADs) makes the search for schools unnecessary.

The techniques used in the culture of top-minnows in Westem Samoa were described by Popper (1979). These hardy bait fish were initially used in trials on board the Tautai Samoa, a twenty-four ton Japanese-built pole-and-line vessel, and on one trip on the Hatsutori Maru No. 5 (the SPC skipjack tagging vessel) early in 1980. These trials had varying degrees of success. They proved, however, that top-minnows, although inferior to many types of wild bait, are suitable for use as live bait and are hardier than most other bait species (see also Baldwin, 1980). These operations, however, did not prove the economic feasibility of such an exercise.

The situation improved considerably after installation of five FADs in Western Samoan waters. ${ }^{3}$ These FADs consisted of a buoy made of two drums in a steel cage, anchored by cable and rope to a concrete block. An appendage, made of copra sacks stitched to a rope, was attached to the buoy. Since it was worn out within a few weeks, the appendage was replaced by old car tyres strung on a chain loop.

One unit, located approximately 14 kilometres ( 9 miles) north of Apia harbour, proved to be very successful. Schools of skipjack (Katsuwonus pelamis) and yellowfin tuna (Thunnus albacares) were almost invariably sighted around it, two or three months after installation. From February to May 1980, most trips of the Tautai Samoa were limited to the distance between Apia and the FAD. The average catch per trip increased substantially (see Tables 1 and 2). The trips lasted only five to six hours, including travelling time, as the limited supply of bait fish was used up.

On 20 May 1980, this FAD disappeared. ${ }^{4}$ After this the catches dropped drastically again and amounted to only two catches in eleven trips, totalling two hundred and seventyfive skipjack. The boat developed engine trouble in mid-August and has been out of commission ever since.

\footnotetext{
1. An earlier version of this paper was presented at the twelfth SPC regional technical meeting on fisheries, held in Noumea, New Caledonia, in November 1980.

2. Present address: C/- Israel Limnology and Oceanography Research Ltd, P.O. Box 1212, Elat, Israel.

3. The first five FADs were funded by the United States Agency for Intermational Deyclopment and installed by the United States National Oceanographic and Atmospheric Administration ị September 1979.

4. This FAD was later found in Fiji with a broken and rusted anchoring cable.
} 
The original five FADs were all lost within eight months, and new FADs were designed and built locally to replace them. ${ }^{1}$. The new devices consisted of two foarn-filled, marine grade, aluminium cylinders with brightly painted boards attached to a mast, equipped with a radar reflector and a light signal. To each device was attached an appendage of twentyfive tyres, strung on a galvanised chain loop.

Table 1: Catches and bait used per trip by Tautai Samoa while fishing by searching for schools (bracketed figures are estimates)

\begin{tabular}{|c|c|c|c|c|c|c|}
\hline \multirow{2}{*}{ Date } & \multirow{2}{*}{ Fishing trip } & \multicolumn{2}{|c|}{ Weight of bait used (kg) } & \multirow{2}{*}{$\begin{array}{l}\text { Number of } \\
\text { fish caught }\end{array}$} & \multirow{2}{*}{$\begin{array}{c}\text { Total weight } \\
\text { of fist caught } \\
\text { (kg) }\end{array}$} & \multirow{2}{*}{$\begin{array}{l}\text { Kilos of fish } \\
\text { caught } / \mathrm{kg} \text { of bait }\end{array}$} \\
\hline & & Cultured & Wild & & & \\
\hline $\begin{array}{l}17.07 .79 \\
08.08 .79 \\
23.08 .79 \\
30.10 .79 \\
06.11 .79 \\
08.11 .79 \\
21.11 .79 \\
27.11 .79 \\
04.12 .79 \\
14.12 .79 \\
18.12 .79 \\
07.01 .80 \\
08.01 .80 \\
11.01 .80 \\
14.01 .80 \\
15.01 .80 \\
22.01 .80 \\
24.01 .80 \\
05.02 .80 \\
07.02 .80 \\
09.04 .80 \\
16.04 .80 \\
21.04 .80 \\
20.05 .80 \\
27.05 .80 \\
13.06 .80 \\
16.06 .80 \\
19.06 .80 \\
23.06 .80 \\
07.07 .80 \\
08.07 .80 \\
15.07 .80 \\
18.07 .80 \\
29.07 .80\end{array}$ & $\begin{array}{r}1 \\
2 \\
3 \\
4 \\
5 \\
6 \\
7 \\
8 \\
9 \\
10 \\
11 \\
12 \\
13 \\
14 \\
15 \\
16 \\
17 \\
18 \\
19 \\
20 \\
30 \\
31 \\
32 \\
43 \\
44 \\
45 \\
46 \\
47 \\
48 \\
49 \\
50 \\
51 \\
52 \\
53\end{array}$ & $\begin{array}{l}50 \\
60 \\
40 \\
50 \\
37 \\
51 \\
26 \\
45 \\
26 \\
50 \\
72 \\
60 \\
68 \\
50 \\
61 \\
35 \\
50 \\
50 \\
70 \\
38 \\
44 \\
40 \\
38 \\
48.5 \\
104.5 \\
54.5 \\
71.5 \\
71.5 \\
48.5 \\
41 \\
46 \\
64.5 \\
68 \\
60.5\end{array}$ & $\begin{array}{c}(45) \\
0 \\
(50) \\
(2.5) \\
0 \\
0 \\
0 \\
0 \\
0 \\
0 \\
0 \\
0 \\
0 \\
0 \\
0 \\
(7.5) \\
(7.5) \\
0 \\
0 \\
0 \\
(100) \\
(20) \\
0 \\
(30) \\
0 \\
0 \\
(7.5) \\
0 \\
(2.5) \\
0 \\
(25) \\
(12.5) \\
0 \\
0\end{array}$ & $\begin{array}{r}340 \\
160 \\
180 \\
167 \\
233 \\
5 \\
161 \\
4 \\
16 \\
64 \\
390 \\
0 \\
0 \\
53 \\
140 \\
0 \\
338 \\
312 \\
0 \\
0 \\
35 \\
0 \\
73 \\
0 \\
0 \\
0 \\
229 \\
0 \\
0 \\
0 \\
0 \\
46 \\
0 \\
0\end{array}$ & $\begin{array}{r}(1024) \\
291 \\
578 \\
364 \\
544 \\
28 \\
372 \\
33 \\
53 \\
291 \\
920 \\
0 \\
0 \\
122 \\
349 \\
0 \\
874 \\
644 \\
0 \\
0 \\
84 \\
0 \\
159 \\
0 \\
0 \\
0 \\
931 \\
0 \\
0 \\
0 \\
0 \\
167 \\
0 \\
0\end{array}$ & $\begin{array}{c}11: 1 \\
5: 1 \\
6: 1 \\
7: 1 \\
15: 1 \\
0.5: 1 \\
14: 1 \\
0: 7: 1 \\
2: 1 \\
6: 1 \\
13: 1 \\
\vdots \\
\dot{2} \\
2: 1 \\
6: 1 \\
- \\
15: 1 \\
13: 1 \\
- \\
- \\
0.6: 1 \\
- \\
4: 1 \\
- \\
- \\
12: 1 \\
- \\
- \\
- \\
\dot{2}: 1 \\
- \\
-\end{array}$ \\
\hline Total & 34 & 1798 & $(310)$ & 2946 & 7828 & - \\
\hline Average & & 52.6 & $(9)$ & 86.6 & 230 & $\cdot$ \\
\hline
\end{tabular}

1. Designed jointly by Fisheries Division and 'Boatcraft', and built at 'Boatcraft'. 
Table 2: Catches and bait used per trip by Tautai Samoa when fishing around fish aggregation device (bracketed figures are estimates)

\begin{tabular}{|c|c|c|c|c|c|c|}
\hline \multirow{2}{*}{ Date } & \multirow{2}{*}{$\begin{array}{c}\text { Fishing } \\
\text { trip }\end{array}$} & \multicolumn{2}{|c|}{ Weight of bait used (kg) } & \multirow{2}{*}{$\begin{array}{l}\text { Number of } \\
\text { fish caught }\end{array}$} & \multirow{2}{*}{$\begin{array}{l}\text { Total weight } \\
\text { of fish caught } \\
(\mathrm{kg})\end{array}$} & \multirow{2}{*}{$\begin{array}{l}\text { Kilos of fish } \\
\text { caught } / \mathrm{kg} \text { of bait }\end{array}$} \\
\hline & & Cultured & wild & & & \\
\hline $\begin{array}{l}20.02 .80 \\
10.03 .80 \\
12.03 .80 \\
14.03 .80 \\
17.03 .80 \\
19.03 .80 \\
21.03 .80 \\
24.03 .80 \\
28.03 .80 \\
22.04 .80 \\
23.04 .80 \\
29.04 .80 \\
01.05 .80 \\
05.05 .80 \\
07.05 .80 \\
08.05 .80 \\
13.05 .80 \\
15.05 .80\end{array}$ & $\begin{array}{l}21 \\
22 \\
23 \\
24 \\
25 \\
26 \\
27 \\
28 \\
29 \\
33 \\
34 \\
35 \\
36 \\
37 \\
38 \\
39 \\
40 \\
41\end{array}$ & $\begin{array}{l}50 \\
59 \\
37 \\
84 \\
64 \\
46 \\
49 \\
21 \\
30 \\
47 \\
47.5 \\
67.5 \\
54 \\
64.5 \\
49.5 \\
69.5 \\
46.5 \\
74.5\end{array}$ & $\begin{array}{l}(7.5) \\
(10) \\
(7.5) \\
(27.5) \\
(17.5) \\
(45)\end{array}$ & $\begin{array}{c}(164) \\
427 \\
323 \\
373 \\
321 \\
172 \\
95 \\
84 \\
29^{*} \\
121^{*} \\
120^{*} \\
488 \\
151 \\
122^{*} \\
65 \\
42 \\
116 \\
67\end{array}$ & $\begin{array}{c}352 \\
852 \\
656 \\
780 \\
656 \\
371 \\
(208) \\
194 \\
57 \\
204 \\
276 \\
979 \\
316 \\
249 \\
125 \\
102 \\
254 \\
311\end{array}$ & $\begin{array}{r}7: 1 \\
14: 1 \\
18: 1 \\
18: 1 \\
5: 1 \\
8: 1 \\
2: 1 \\
9: 1 \\
2: 1 \\
4: 1 \\
5: 1 \\
13: 1 \\
5: 1 \\
4: 1 \\
3: 1 \\
1: 1 \\
4: 1 \\
3: 1\end{array}$ \\
\hline Total & 18 & 960 & $(235)$ & 3280 & 6942 & - \\
\hline Average & & 53 & (13.1) & 182.2 & 385.7 & - \\
\hline
\end{tabular}

* Includes some fish not caught at FAD.

The first new FAD was anchored 16 kilometres (10 miles) north of Apia on 15 September 1980. Schools of skipjack and yellowfin tuna were sighted around it within one month. Nine additional FADs were anchored subsequently, and also proved successful.

The first trial in pole-and-line fishing with a small boat was carried out on 10 October 1980. The boat used was Tautai Nouei, (see Figure 1), a modified "alia"1 (a 29-ft (approximately $9 \mathrm{~m}$ ) locally built, aluminium catamaran). The modifications included two 400 litre bait wells, one in each hull, and a spraying system (see Figures 2 and 3). The bait wells werre replenished with fresh sea water through a forward directed pipe and overflow holes when the boat was in motion. The spray system consisted of $2 \mathrm{~mm}$ (1/16") holes, drilled in the hollow stern beam. The latter were connected through a $50 \mathrm{~mm}$ (2") hose to a $3 \mathrm{hp} \mathrm{"Honda'} \mathrm{pump.} \mathrm{This} \mathrm{system} \mathrm{provided} \mathrm{a}$ fine spray, reaching to a distance of 3 to 4 metres (10' to $\left.13^{\prime}\right)$.

This first fishing trip was carried out with five fishermen and a chummer. Thirty kilograms of live top-minnows were chummed near the FAD between 0930 and 1030 hours on a cloudy day with a calm sea. Despite technical problems with the pump, 41 fish, totalling $142 \mathrm{~kg}$, were caught. The results improved gradually in subsequent fishing trips at different times of day and in calm or rough weather. On 29 October, $116 \mathrm{fish}$, totalling $288 \mathrm{~kg}$, were landed. On 30 October, however, (following the night of the rising of the palolo worm), only 27 fish were caught. In a total of 60 similar fishing trips (Table 3 ), $1400 \mathrm{~kg}$ of mollies were used under varying weather conditions, and $2840 \mathrm{fish}$, totalling $7500 \mathrm{~kg}$, were caught.

1. The "alia", made of plywood or aluminium, are being built at 'Boatcraft', an FAO/UNDP-supported project. The boats were designed by $F A O$ naval architects $O$. Gulbrandsen and $A$. Overa. 


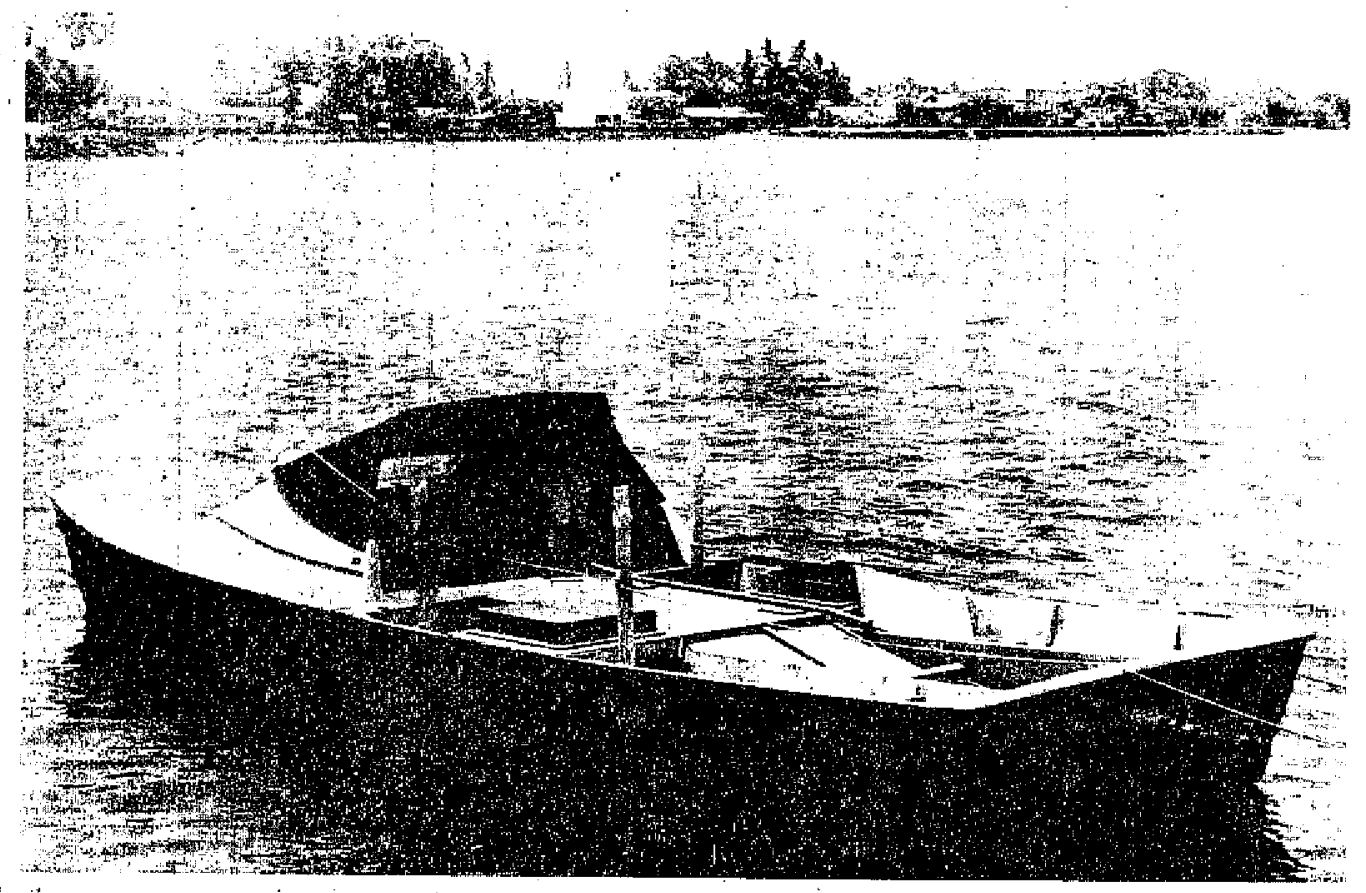

Figure 1: The 'Tautai Nouei', a modified 'alia' catamaran used for pole-and-line fishing experiments in Western Samoa.

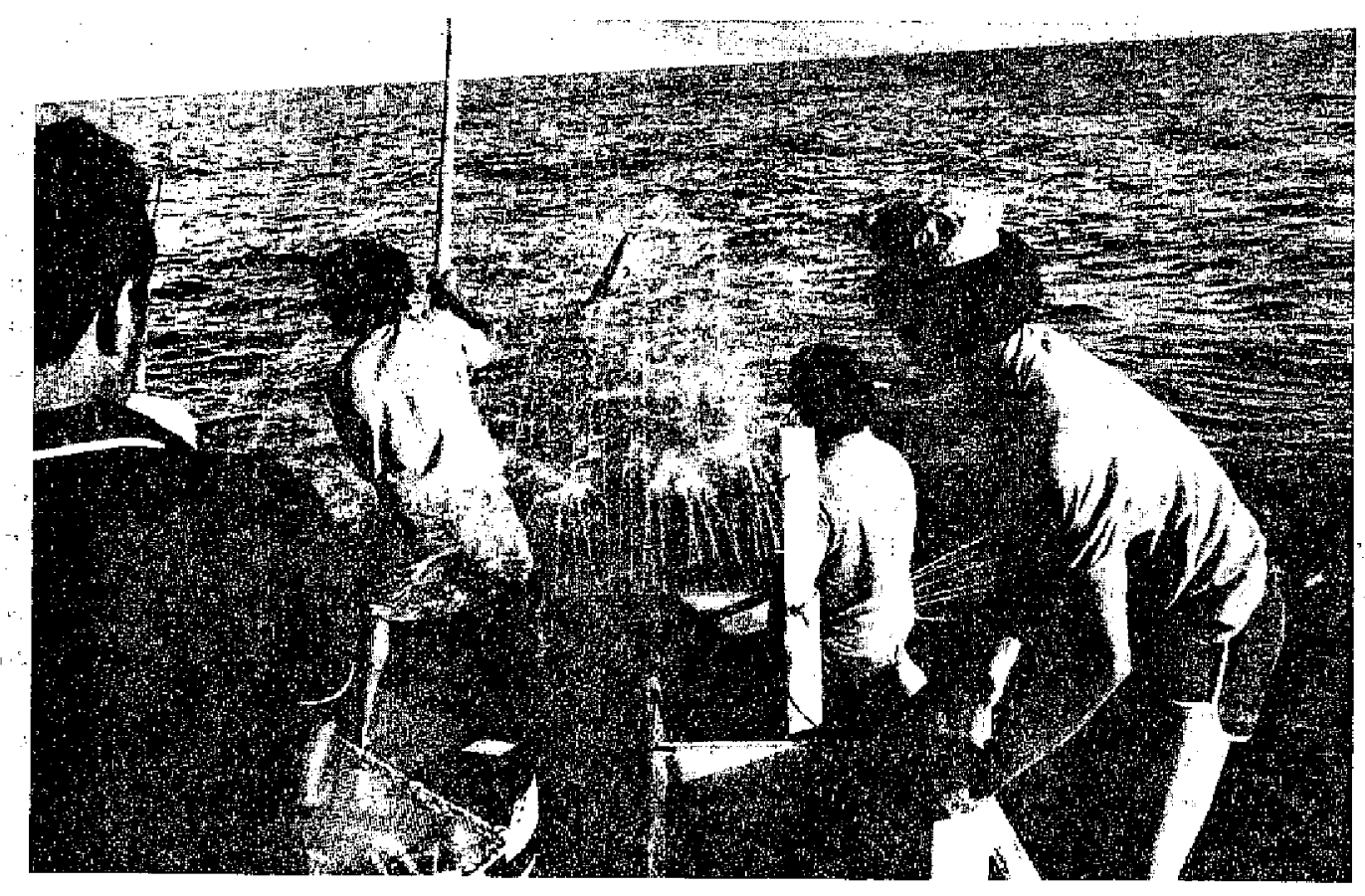

Figure 2: Poling in a skipjack on board a privately owned 'alia'. The chummer is standing at the left of the picture with net in hand. 
Table 3: Catches and bait used per trip by smali boats fishing at fish aggregation devices*.

T.N. = Tautai Samoa (Fisheries Division boat)

Bait size 5: $0.8 \mathrm{~g}$

priv. $=$ private boat

Bait size 6: $1.6 \mathrm{~g}$

\begin{tabular}{|c|c|c|c|c|c|c|c|c|c|}
\hline 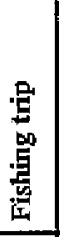 & 焉 & 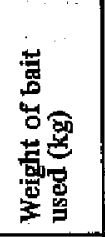 &  & 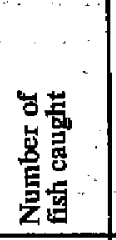 & 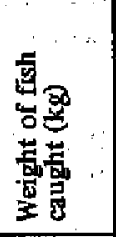 & 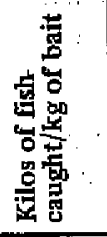 & 㟶 & 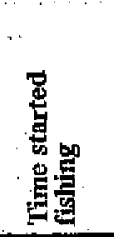 & 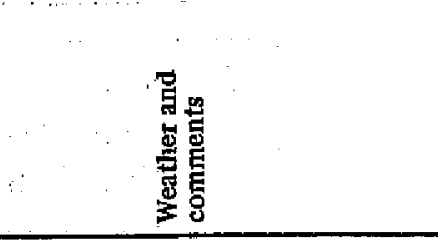 \\
\hline \begin{tabular}{r|}
1 \\
2 \\
3 \\
4 \\
5 \\
6 \\
7 \\
8 \\
9 \\
10 \\
11 \\
12 \\
13 \\
14 \\
15 \\
16 \\
17 \\
18 \\
19 \\
20 \\
21 \\
22 \\
23 \\
24 \\
25 \\
26 \\
27 \\
28 \\
29 \\
30 \\
31 \\
32 \\
33 \\
34 \\
35 \\
36 \\
37 \\
38 \\
39 \\
40 \\
41 \\
42 \\
43 \\
44 \\
45 \\
46 \\
47 \\
48 \\
49 \\
50 \\
51 \\
52 \\
53 \\
54 \\
55 \\
56 \\
57 \\
58 \\
59 \\
60 \\
61 \\
\end{tabular} & $\begin{array}{l}10.10 .80 \\
23.10 .80 \\
24.10 .80 \\
24.10 .80 \\
28.10 .80 \\
28.10 .80 \\
29.10 .80 \\
30.10 .80 \\
31.10 .80 \\
05.11 .80 \\
06.11 .80 \\
11.11 .80 \\
12.11 .80 \\
18.11 .80 \\
19.11 .80 \\
20.11 .80 \\
21.11 .80 \\
25.11 .80 \\
26.11 .80 \\
28.11 .80 \\
02.12 .80 \\
07.12 .80 \\
08.12 .80 \\
09.12 .80 \\
10.12 .80 \\
11.12 .80 \\
12.12 .80 \\
13.12 .80 \\
15.12 .80 \\
16.12 .80 \\
17.12 .80 \\
16.01 .81 \\
17.01 .81 \\
19.01 .81 \\
21.01 .81 \\
22.01 .81 \\
23.01 .81 \\
24.01 .81 \\
27.01 .81 \\
29.01 .81 \\
31.01 .81 \\
03.02 .81 \\
04.02 .81 \\
04.02 .81 \\
06.02 .81 \\
09.02 .81 \\
11.02 .81 \\
13.02 .81 \\
14.02 .81 \\
15.02 .81 \\
17.02 .81 \\
18.02 .81 \\
21.02 .81 \\
22.02 .81 \\
24.02 .81 \\
25.02 .81 \\
28.02 .81 \\
01.03 .81 \\
04.03 .81 \\
06.03 .81 \\
07.03 .81 \\
\end{array}$ & $\begin{array}{l}30 \\
50 \\
45 \\
70 \\
43 \\
30 \\
28 \\
30 \\
20 \\
35 \\
30 \\
31 \\
35 \\
27 \\
5 \\
23 \\
23 \\
30 \\
24 \\
31 \\
28 \\
22 \\
30 \\
40 \\
34 \\
30 \\
37 \\
28 \\
25 \\
25 \\
30 \\
30 \\
29 \\
18 \\
21 \\
24 \\
17 \\
18 \\
26 \\
21 \\
28 \\
28 \\
18 \\
21 \\
26 \\
22 \\
16 \\
24 \\
25 \\
8 \\
20 \\
15 \\
24 \\
6 \\
29 \\
23 \\
23 \\
5 \\
25 \\
18 \\
39 \\
\end{array}$ & \begin{tabular}{|l|} 
Mixed \\
Mixed \\
Mixed \\
Mixed \\
Mixed \\
Mixed \\
Mixed \\
Mixed \\
Mixed \\
Mixed \\
Mixed . \\
Mixed \\
Mixed \\
Mixed \\
Mixed \\
Mixed \\
Mixed \\
Mixed \\
Mixed \\
Mixed \\
Mixed \\
Mixed \\
Mixed \\
Mixed \\
Mixed \\
Mixed \\
Mixed \\
Mixed \\
Mixed \\
Mixed \\
Mixed \\
6 \\
5 \\
5 \\
6 \\
5 \\
$5+6$ \\
$5+6$ \\
$5+6$ \\
6 \\
5 \\
5 \\
$6+$ Mixed \\
5 \\
5 \\
5 \\
5 \\
5 \\
6 \\
5 \\
6 \\
5 \\
6 \\
5 \\
$5+6$ \\
6 \\
6 \\
5 \\
$5+6$ \\
5 \\
$5+6$ \\
\end{tabular} & $\begin{array}{r}41 \\
42 \\
41 \\
51 \\
105 \\
36 \\
116 \\
27 \\
- \\
45 \\
3 \\
70 \\
30 \\
38 \\
-4 \\
34 \\
78 \\
61 \\
42 \\
101 \\
20 \\
31 \\
61 \\
66 \\
60 \\
47 \\
101 \\
72 \\
.55 \\
37 \\
38 \\
25 \\
85 \\
18 \\
101 \\
75 \\
17 \\
85 \\
69 \\
109 \\
129 \\
66 \\
38 \\
38 \\
38 \\
38 \\
10 \\
116 \\
114 \\
48 \\
73 \\
8 \\
146 \\
44 \\
66 \\
98 \\
66 \\
44 \\
48 \\
35 \\
85 \\
\end{array}$ & $\begin{array}{r}142 \\
143 \\
134 \\
167 \\
285 \\
114 \\
288 \\
86 \\
- \\
138 \\
8 \\
229 \\
94 \\
104 \\
- \\
82 \\
163 \\
147 \\
118 \\
293 \\
67 \\
95 \\
166 \\
152 \\
129 \\
131 \\
233 \\
161 \\
130 \\
79 \\
122 \\
58 \\
180 \\
41 \\
235 \\
172 \\
40 \\
230 \\
193 \\
317 \\
368 \\
134 \\
138 \\
129 \\
120 \\
87 \\
25 \\
280 \\
290 \\
105 \\
170 \\
177 \\
156 \\
238 \\
210 \\
99 \\
180 \\
\end{array}$ & $\begin{array}{c}5 \\
3 \\
3 \\
2 \\
7 \\
4 \\
10 \\
3 \\
- \\
4 \\
0.3 \\
7.5 \\
2.6 \\
4 \\
5 \\
2 \\
7 \\
5 \\
5 \\
9.5 \\
2.5 \\
4.3 \\
5.5 \\
3.7 \\
3.8 \\
4.4 \\
6.3 \\
5.8 \\
5.2 \\
3 \\
4 \\
2 \\
6.2 \\
2.3 \\
11 \\
7.2 \\
2.3 \\
13 \\
7.5 \\
15 \\
13 \\
6.5 \\
7.7 \\
6.1 \\
4.6 \\
.4 \\
1.6 \\
11.7 \\
11.6 \\
13.1 \\
-8.5 \\
1.1 \\
20.2 \\
26 \\
8.2 \\
14.7 \\
9.1 \\
1 \\
4 \\
4 \\
4.5 \\
\end{array}$ & 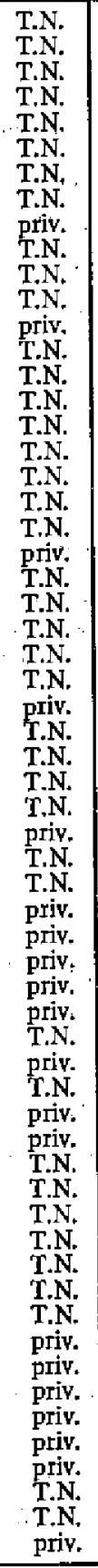 & $\begin{array}{l}11 \\
12 \\
08 \\
10 \\
14 \\
15 \\
10 \\
15 \\
16 \\
16 \\
14 \\
07 \\
12 \\
11 \\
11 \\
10 \\
10 \\
11 \\
10 \\
10 \\
06 \\
15 \\
10 \\
10 \\
10 \\
10 \\
07 \\
\end{array}$ & $\begin{array}{l} \\
\text { Sunny } \\
\text { Cloudy } \\
\text { Half cloudy } \\
\text { Cloudy and rain } \\
\text { Part cldy, dolphins } \\
\text { Large schools of wild bait } \\
\text { Sunny, large sclools feed } \\
\text { Dolphins disrupt } \\
\text { Dolphins disrupt } \\
\text { Rough sea } \\
\text { Cloudy after-rain } \\
\text { Rainy } \\
\text { Part cloudy, rough } \\
\text { Rough sea, stop fishing } \\
\text { Cloudy after stom } \\
\text { Sunny } \\
\text { Sunny } \\
\text { Sunny : } \\
\text { Sunny, calm, much wild bait } \\
\text { Cloudy } \\
\text { Sunny and rough } \\
\text { Sunny } \\
\text { Partly cloudy } \\
\end{array}$ \\
\hline \multicolumn{2}{|c|}{ Total } & 1616 & & 3441 & 9433 & - & & & \\
\hline \multicolumn{2}{|c|}{ Average } & 26.5 & & 56.4 & 154.6 & 6.3 & & & \\
\hline
\end{tabular}

*On 23 March 1981, a record of 208 fish totalling $580 \mathrm{~kg}$ was caught by Tautai Nouei. Sixteen kilograms of size 5 mollies were used. 
An approximate idea of the economics involved in the method described is given in Table 4. Table 5 gives the costs for constructing and installing the FAD.

Table 4: Estimated costs and profit per fishing trip for small-scale pole-and-line fishing around an FAD. (WS $\$ 1.00$ was worth approximately US\$1.20 in 1980)

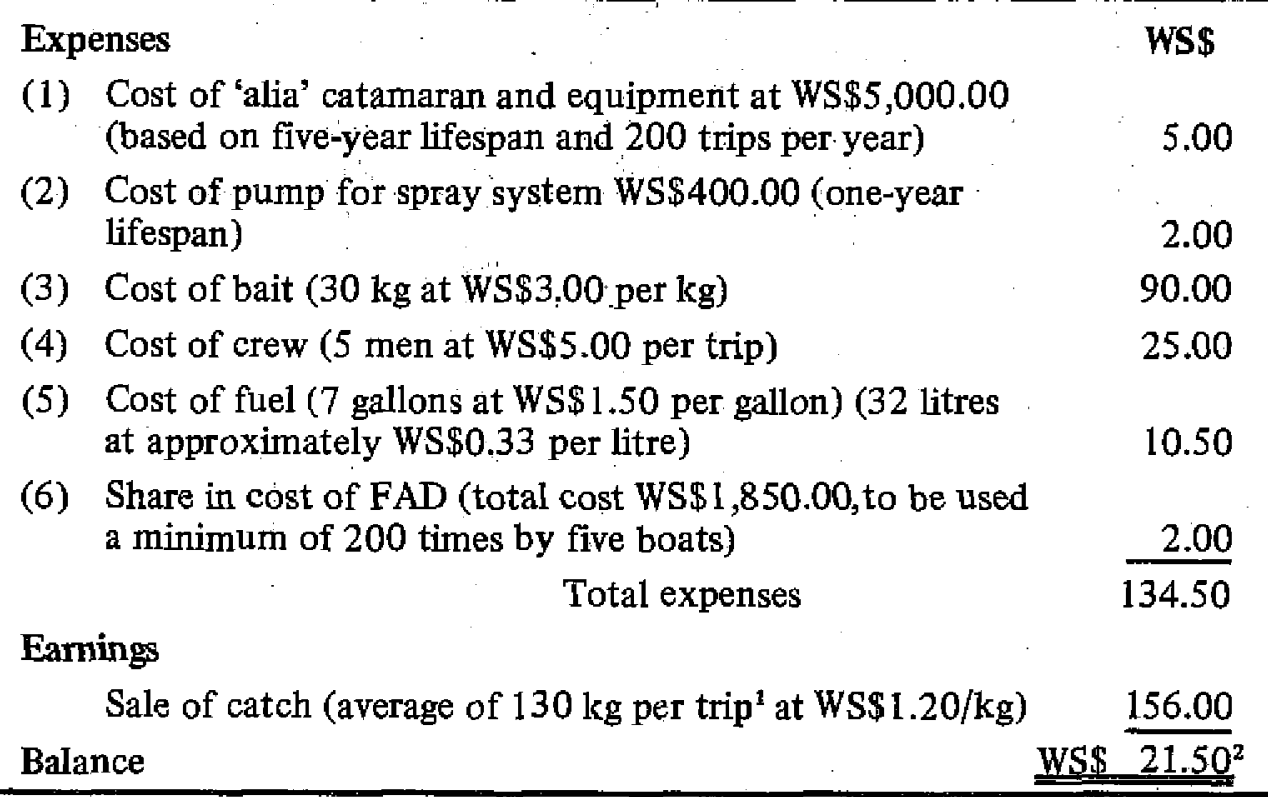

1. This average is based on information presented in this paper as well as subsequent experience.

2. In 1981 , the price of tuna rose to WS\$1.30/kg while fuel rose to WS\$2.10/gal. (approximately WS $\$ 0.47 / 1$. Based on these figures, comparable ffgures for 1981 are:

expenses : WS $\$ 138.70$

eamings : WS\$169

balance : WS $\$ 30.30$

Table 5: Cost for construction and installation of aggregation device (US dollars)

\begin{tabular}{|lr|}
\hline (1) Buoy with attachments for mooring and & US $\$$ \\
appendage (all from Boatcraft, Apia) & 850.00 \\
(2) Anchor rope and chain & 900.00 \\
(3) $\begin{array}{l}\text { Echosounder and mounting at US } \$ 6,000.00 \\
\text { (to be used for deploying many devices) } \\
\text { Total }\end{array}$ & $\frac{100.00}{1,850.00}$ \\
\hline
\end{tabular}

It is felt that these results, if substantiated by further trials, will have considerable significance to fisheries development in Samoa and other Pacific Island countries. The relative simplicity, low cost and small scale of the suggested fishery will make it suitable for entrepreneurs and fishermen at the village level. This will be the case if FADs are properly located in the fishing ground concerned. 


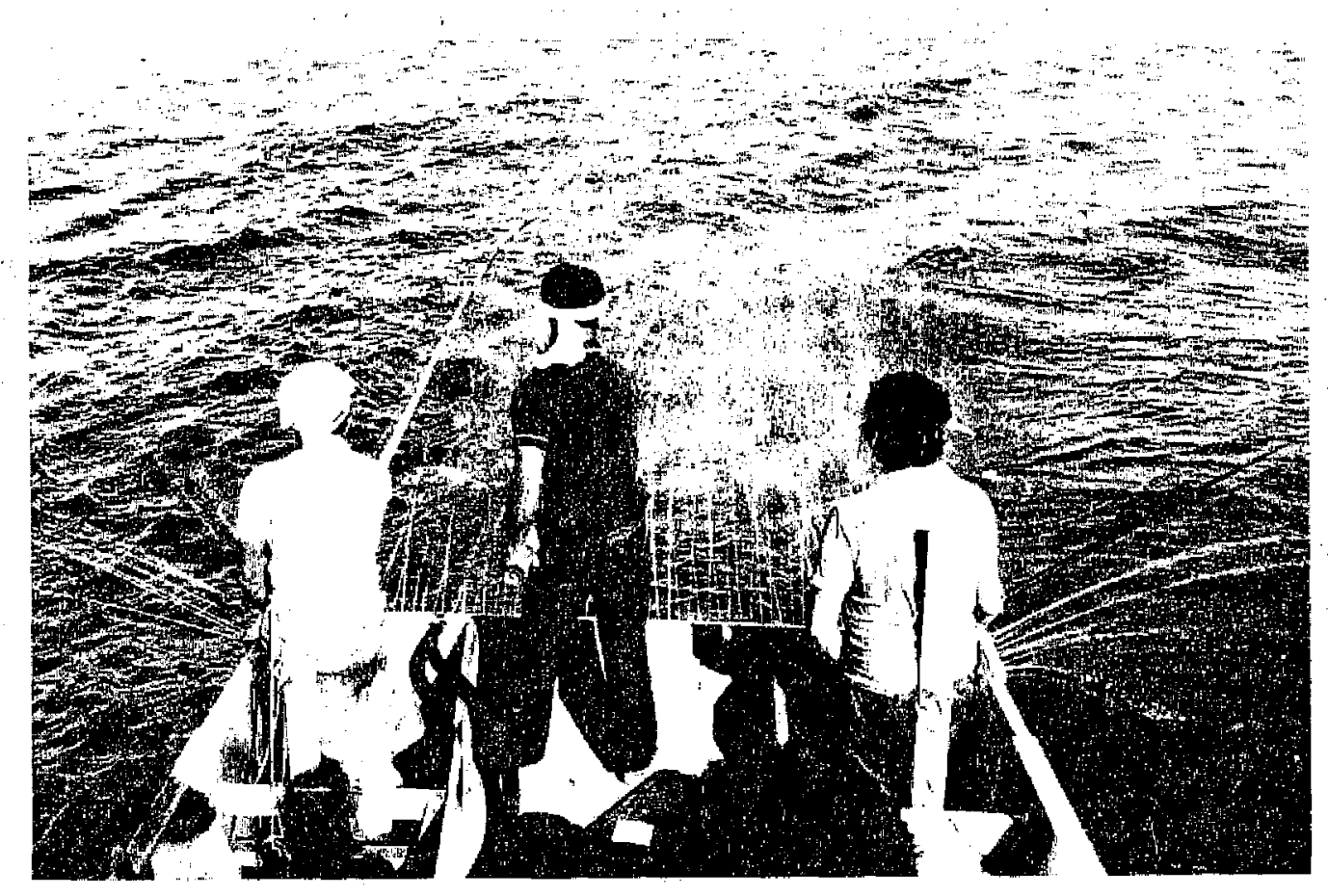

Figure 3: Pole-and-line fishing on board a privately owned 'alia'.

Note the spray system.

\section{References}

Baldwin, E.G. 1980. Final report - Culture of bait fish. Mimeo. Report prepared for University of Hawaii, Sea Grant College, 63 pp.

Bryan, P.G. 1978. On efficiency of mollies (Poecilia mexicana) as live bait for pole-and-line skipjack fishing: fishing trials in the tropical Central Pacific. Mimeo. Technical Report of Project No. 4-35-D. Prepared for the Office of Marine Resources, American Samoa, $45 \mathrm{pp}$.

Popper, D.M. 1979. FAO/UNDP Bait Culture Project; Western Samoa. Mineo. Information paper presented to the twelfth South Pacific Commission regional technical meeting on fishleries. 


\title{
HAWAIIAN ‘AKULE’ NIGHT FISHING GEAR
}

\author{
R. Powell \\ formerly Fisheries Officer, South Pacific Commission, Noumea
}

The South Pacific Commission has received a number of requests for information on smallscale fishing methods which have been developed in particular countries throughout the Pacific and which might have application elsewhere in the region. To this end, we are publishing below the first in a series of articles on such techniques. This article is based on a pamphlet, now out of print, produced for an SPC fishing techniques course held in Palau in 1968.

\section{Introduction}

The fish known in Hawaii as 'akule', Selar crumenopthalmus, (Figure 1) occurs in hundreds of islands across the Pacific where it is known by a number of local names. Quite frequently, the fish is known by a different name at each stage of its growth. The mature fish is known by the following names in some of the Pacific islands:

$\begin{array}{ll}\text { Cook Islands } & \text { Ature, Aturepai } \\ \text { Niue } & \text { Atule } \\ \text { Tahiti } & : \text { Ature, Aramea, Oräe } \\ \text { Tonga } & : \text { Otule } \\ \text { Samoa } & : \text { Otule } \\ \text { Solomon Islands } & : \text { Buma }\end{array}$

The common English name is 'big-eyed scad'.

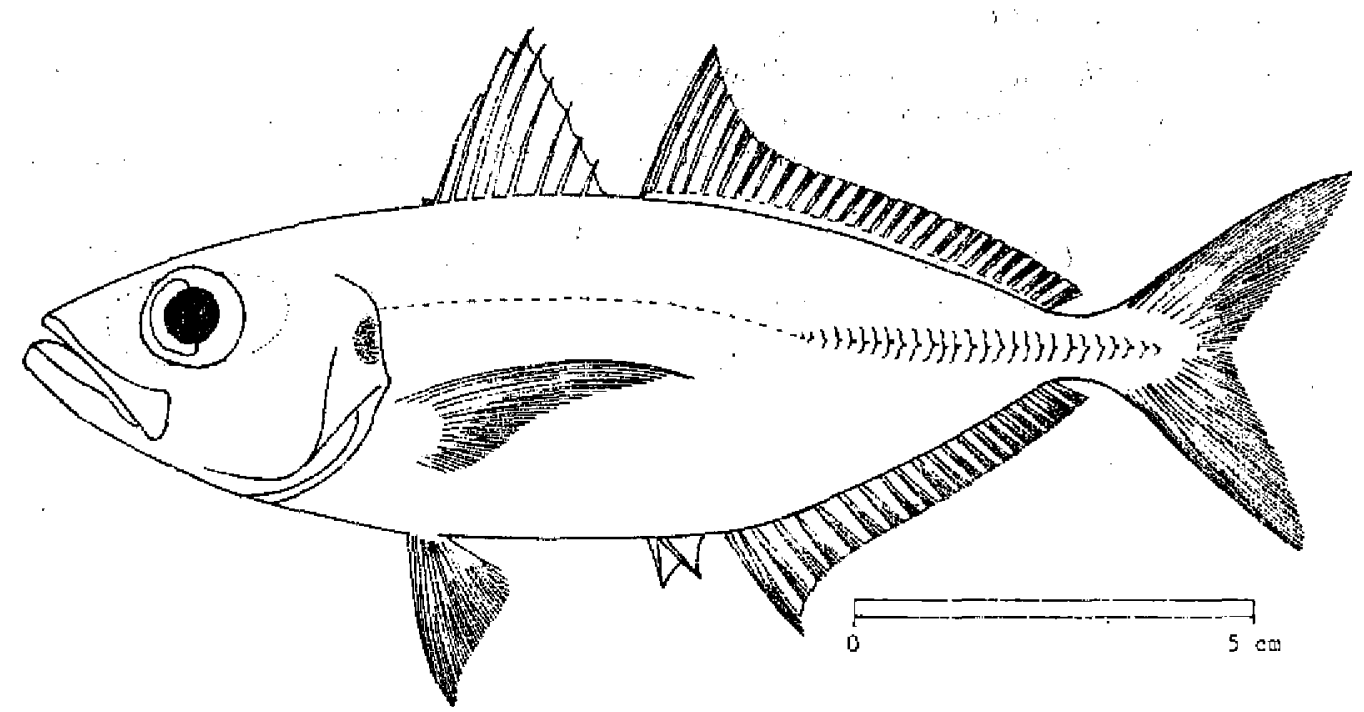

Figure 1: 'Akule' (Selar crumenopthalmus)

Illustration from Species identification sheets for fishery purposes: eastem Indian Ocean fishing area 57 and westem central Pacific fishing area 71, vol. 1, Rome: FAO, 1974.

The Hawaiians have developed a commercial fishery for akule caught using lights and artificial lures as described in this paper. Similar gear and methods can also be used to catch opelu or mackerel scad (Decapterus spp.).

Akule occur in big schools in the shallow water of bays, harbours and reef entrances in most Pacific islands. Under these conditions they are traditionally caught with surround nets, 
or scare lines. When the fish move out of the shallow water inshore, these traditional methods are of no use. The method described here is designed to catch the larger fish offshore in relatively deep water beyond the reef.

The fish are most easily caught when they spawn. This occurs in the southern hemisphere during the summer months of November and December. In the northern hemisphere, June and July are the times when greatest catches can be expected.

Within theșe months the best fishing nights are close to the new moon when the longest periods of darkness occur. As the moon sets later, the period of time in which it is opportune to fish decreases. Close to full moon, this method is of little use.

A very light, offshore breeze is best for this type of fishing. Under such conditions it is possible to anchor with the boat held off the reef by the wind, with little danger of being set into the breakers. On nights when the wind is strong onshore and the sea is rough, fishing becomes difficult and sometimes dangerous.

\section{Light source}

All the Hawaiian fishermen use electric light. In larger vessels where a d.c. generator can be run continuously, electric light offers few problems. In a small boat or canoe a heavy-duty storage battery is the most convenient power pack. A 12-volt 25-watt electric light bulb will give a steady light all night if supplied from a fully charged, heavy-duty battery. This light bulb can be easily shaded by mounting it inside a plastic or aluminium bucket which is, in turn, held in place by a bracket made from standard 3/4" $(2 \mathrm{~cm})$ pipe fittings.

The liglit shade is illustrated in Figure 2. When mounting this shade it is important to make sure that the shade does not dip below the surface in rough water. If, in turn, it does reflect just sufficient light to enable the fishermen to see to untangle their lines, it is a great advantage. A light which is bright inboard makes handling gear easy, but is a danger when one needs to watch for navigational hazards incidental to this fịshing. As every fisherman knows, it is generally better, wher working at night, to get one's eyes accustomed to the darkness rather than use bright illumination to work with and suffer partial blindness in areas outside the field of light.

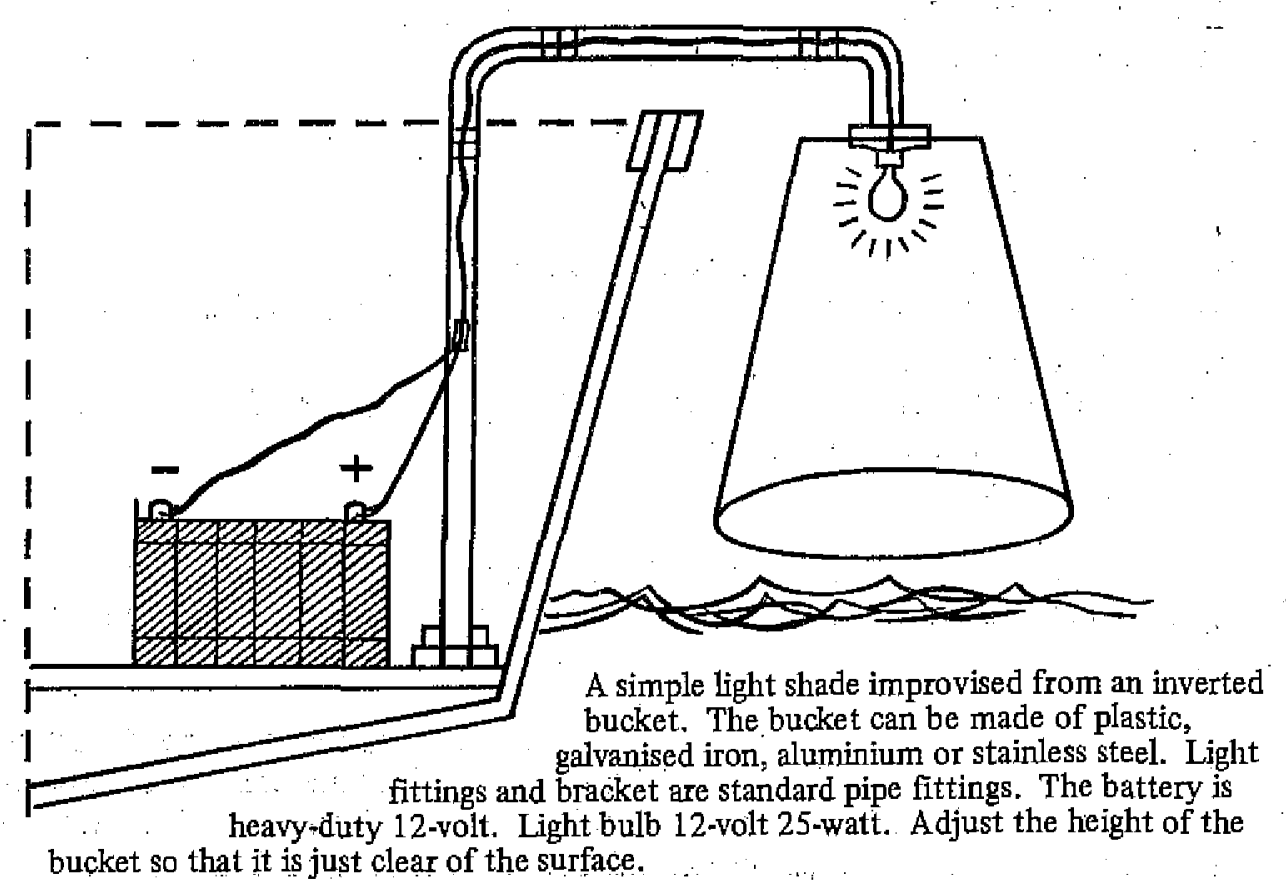

Figure 2: The light shade 
A long canoe is a convenient type of vessel for this type of fishing. If the light is mounted in the centre of the canoe, it is possible for two men to fish, one from each end of the canoe, so that the lines do not tangle. When a small boat is used, it is problematical as to just how far two lines should be separated so that cross-overs and tangles do not occur. A $20 \mathrm{ft}$ (approximately $6 \mathrm{~m}$ ) boat with a light mounted in the centre provides a convenient platform for two fishermen to work; although smaller boats can be used if some care is taken.

All Pacific fishermen who are familiar with catching flying fish at night have noticed that large fish often circle round a bright light but seldom swim close to it. It is only when one can concentrate the light into a small cone close under the boat that akule fishing becomes possible. Once a shaded light is used so that the pool of light is only about 2 metres $(6 \mathrm{ft})$ in diameter, all the marine life concentrates into and around this small circle. This makes fishing much easier.

Given a good fishing night, when the moon sets soon after sunset and with a light, offshore breeze and the sea calm without a strong current, fishing can start as soon as twilight fades. When the light is first switched on, very little is likely to happen for the first hour. Then gradually a few very small planktonic animals will appear. Once these zooplankton have collected in the circle of light, it is not long before larger fish move in and begin feeding. Within the next few hours more plankton will collect and a wide variety of small fish will be actively feeding. It will be noticed that the small fish stay within the circle of bright light while the larger fish stay further away. Even larger fish stay outside this circle of half light and often dart in to snatch a. smaller fish. The akule are, in turn, attracted and begin feeding on the fast-moving plankton.

\section{The fishing gear}

It is common in Hawaii to use a line of five to six hooks, as illustrated in Figure 3A. However, any number of hooks can be used, depending on the preference of the individual fishermen.

The line is made up as follows:

- line for mainline: about 16. kilos ( $35 \mathrm{lbs}$ ) test, either three strands of monofilament loosely braided together or some suitable braided multifilament;

- line for snoods: monofilament of 4.5 to 9 kilos ( 10 to $20 \mathrm{lbs}$ ) test. The snoods are attached to the centreline by loop knots and should be $38 \mathrm{~cm}(15$ ") to $51 \mathrm{~cm}(20$ ") long and spaced sufficiently to prevent their tangling.

(Note: for the centreline and snoods, white nylon is satisfactory for akule but black is essential for opelu.);

- a small swivel (attached where the mainline joins the centreline);

- a terminal lead of about $.06 \mathrm{~kg}(2 \mathrm{oz})$.

Most fishermen will prefer to make up their own lures.

Akule lures (Figure 3B) can be made out of a variety of materials. These include:

- white nylon knitting wool,

- white feathers (traditionally those from the breast of a tropic bird),

- bristles from the tail of a white dog or pig,

- fibreglass floss.

The best hooks for the purpose are Mustad Limerick ringed, tinned; extra strong quality $8235 \mathrm{H}$. Size 6 is an average size; larger sizes can be used to advantage when large akule are biting.

The lures are made up simply by passing the wool or similar material through the eye of the hook, binding the wool to the shank of the hook with a few turns of cotton (often red cotton is preferred) and teasing the wool to make a lure as illustrated. It is advisable to make a number of lures, as many are lost in use and also they lose their efficiency after repeated use.

Lures for opelu must be made with black wool or feathers and with slightly smaller hooks. (Akule will also take black lures at times.) 


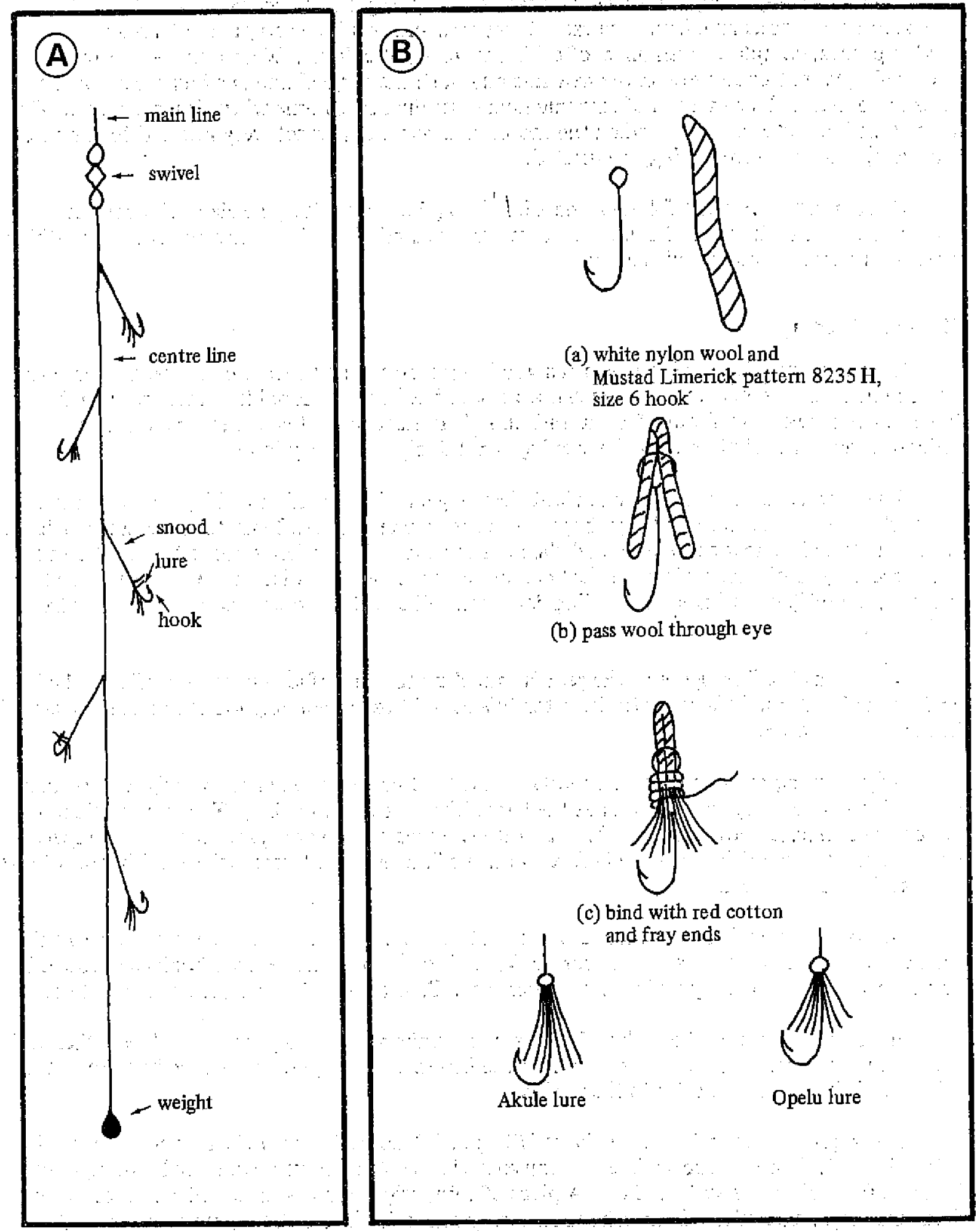

Figure 3: A: Layout of terminal rig. B: Method of making lures using wool. 
When working at night in semi-darkness, it is easy to get line and snoods tangled. This can become a serious problem. The easiest way to avoid this is to carry about half-a-dozen made up lines, complete with lures ; of different sizes and colours. When a snarl-up occurs, it is then a simple matter to use a whole new line and push the tangled line in a box for attention later in daylight. This method of carrying numerous lines saves time when fish are biting. Time is the limiting factor on nights when the moon rises very early or sets very late and the hours of darkness, and therefore fishing, are limited.

It is a great help when fishing to rig a bamboo pole round the gunwale of the boat over which lines will be hauled. Bamboo stands up to repeated chafe from lines better than anything else. It is easy to replace and is cheap.

\section{Method of fishing}

Let us assume that we have chosen a good night with a light breeze offshore, the sea calm and the night of the new moon. The canoe or boat has been anchored in a likely place offshore beyond the breakers in about 15 to 20 fathoms. The electric light is turned on soon after twilight fades. The first hour of the evening is not likely to be very busy.

After about an hour it will be noticed that very small zooplankton will gather under the light. Soon we notice a few silvery shapes deep down where it is difficult to recognise individual fish. The time has now come to uncoil the lines for about five fathoms above the small swivel. It is necessary to choose a place on the boat so that the line is handled in the zone-between the bright circle of light and the surrounding darkness. The best place will soon be found by trial and error.

As soon as the line tightens, the gear is hauled up to the surface until the small swivel clicks against the bamboo. It is easier to listen for this sound than to actually look for this small swivel in the semi-darkness.

When hauling the line, it is all important that the line be retrieved at a steady, continuous speed. This is not easy to do at first as the hands change over in hauling. The line should not be retrieved in jerks, but in a smooth, steady flow. It may take some practice to get the speed of retrieving to the critical rhythm before the fish will bite. Once this is achieved, fish attack these lures and are easily hooked.

The akule have a hard mouth and it takes a few seconds to unhook each fish. During this time other fish will often take the lower hooks. It is easy to get these small hooks embedded in one's fingers when working under these conditions. Practice is, of course, the only solution.

As the night goes on, the fish will increase in numbers and on a good night they gather under the light in huridreds. It will be noticed that the largest fish are generally on the bottom of the school and the smaller fish rise to the surface.

The larger fish generally weigh about $1 / 2 \mathrm{~kg}(1 \mathrm{lb})$, sometimes a little heavier. The smaller fish swim actively about the surface and can sometimes be caught more quickly by using a thin bamboo fish pole and a suitable lure. A piece of thin, bright akule skin cut with a razor blade from the bright side of the fresh fish makes a very attractive lure at times, but on other nights a variety of different lures will be found more effective. The larger fish seldom break surface and the fishermen will have to decide whether a lot of small fish is more valuable than a smaller number of large fish.

\section{Bait and lures don't mix}

Akule have been caught traditionally by using a variety of different baits. In every island group, successful fishermen can be found who will make good catches at night using ground fish as chum. Then by baiting their hooks with small pieces of cut bait, and under good conditions, some successful catches can be made. 
Where fishermen are using this time-honoured method of fishing, it is most unlikely that anyone will be entirely successful by using the method described above.

It is difficult to decide why the two methods of fishing will not work side by side. It is probable that when fish are feeding hungrily on zooplankton, they are feeding visually. Their reactions are then quite different from the reactions of the same fish, which, while feeding on ground chum, are possibly feeding by sensing or smelling the ground bait in the water. Under such conditions they are not feeding visually and they fail to be attracted by the zooplankton until the bait and chum are removed.

The night can be going well for the fishermen using lures, with fish feeding in a frenzy, only to end suddenly when someone liberates some finely ground fish in the area. When this happens, it is necessary to up-anchor and move off to another area, thus wasting an hour or more before a new sequence of fishing can begin. sunrise.

On good nights when conditions are favourable, fish will continue to bite well until nearly

Moonlight nights are seldom successful, although catches can sometimes be made by lowering the gear down into much deeper water. Akule swim down to at least 70 fathoms, at times perhaps even deeper. But it is slow fishing when every fish has to be hauled all this distance and most fishermen will prefer to change over to other methods of fishing during the bright nights of the moon. 


\title{
FIJI FISHERIES DIVISION'S BOAT-BUILDING AND RURAL TRAINING SCHEME
}

\author{
M.T. Gentle
}

A boat-building and rural training scheme was initiated by Fiji Fisheries Division in January 198.1 to provide village fishermen with cheap, efficient fishing vessels as well as practical training in modern small-scale fishing methods. Under the scheme, trainees attend a six-month training course at fisheries headquarters at Lami, Suva, during. which they build their own boats, with the assistance of the Division's boat-building staff, and are trained in the use and maintenance of the boats' and gear.

According to Chief Fisheries Officer, Dr Peter Hunt, the emphasis of the course is to involve the trainees at all stages of the boat-building process. As the building of the boat progresses, each trainee receives basic instruction in the maintenance of the boat and its equipment and, perhaps more importantly, feels a sense of involvement and achievement. This approach has the further advantage of keeping costs to a minimum. Trainees return to their villages with fully equipped, multi-purpose fishing boats and the ability to use them competently and safely.

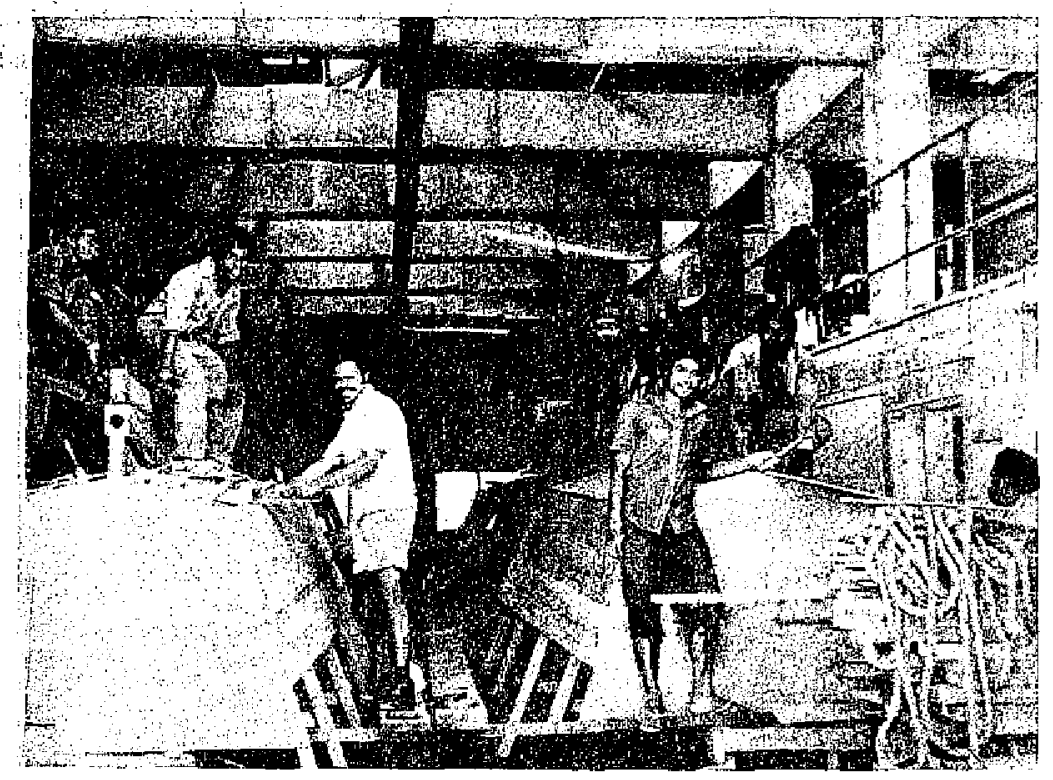

Trainees working on the hulls in the boatshed

The type of boat being built under the scheme is the well-known 28 -ft $(8.5 \mathrm{~m})$ LOA plywood V-bottom launch, first built by the FAO boat-building project in Western Samoa, and which has proven extremely popular among Fijian fishermen. The original design has been modified slightly to give extra cabin space and, to compensate for the resulting increase in windage and weight, the beam has been increased by 10 inches $(.25 \mathrm{~m})$ to 8 feet $(2.4 \mathrm{~m})$. Local woods are used for the frames, bearers and keel. Each boat comes fully equipped with a $20 \mathrm{hp}$ Yanmar diesel engine, anchor and anchor rope, $2.4 \mathrm{ft}^{3}\left(.07 \mathrm{~m}^{3}\right)$ ice box, echosounder, petrol-driven line hauler, a two-burner gas stove, an auxiliary sail, and fishing gear including wooden handreels for deep bottoin fishing, handlines ('Super-Toto') and gill nets.

Building the boat and installing the engine take up the first three months of the training programme. In the following two months there is a block course which covers gear technology (net-making and repairs, use of the echosounder and line hauler, rigging of handlines and construction of Z-type fish traps) as well as instruction in fish preservation (icing, salting), bêchede-mer processing, first aid, safety at sea, basic coastal navigation and elementary business management. The course concludes with a month of supervised practical fishing. 
The total cost to the trainees is $F \$ 4,800$ (approximately US $\$ 5,200$ ) which covers both the cost of the boat as well as food and accommodation during the course. Loans are available for the full amount, repayable over a three-year period at an interest rate of five per cent per annum. Trainees pay only for labour and the costs of materials used in construction of the boat; the engine, line hauler, echosounder and other imported items are provided free under Japanese aid, while the nets, wooden handreels and ice box are made by the trainees themselves as part of the course. The trainees are accommodated in a specially built hostel, also provided under Japanese aid.

All the trainees have a background as successful village fishermen and most come from registered fishing groups or co-operatives. Candidates are initially recommended by Roko Tuis (village chiefs) and other village-level administrative officers. The final selection is carried out by the Fisheries Division in consultation with the Ministry of Fijian Affairs and Rural Development and is made on the basis of background, experience and geographical area. Priority is given to candidates from areas of low agricultural potential and those with underexploited fishery resources. At present, the scheme can accept two groups of nine trainees each year. More places will be available in future when more space becomes available in the boat-building shed.

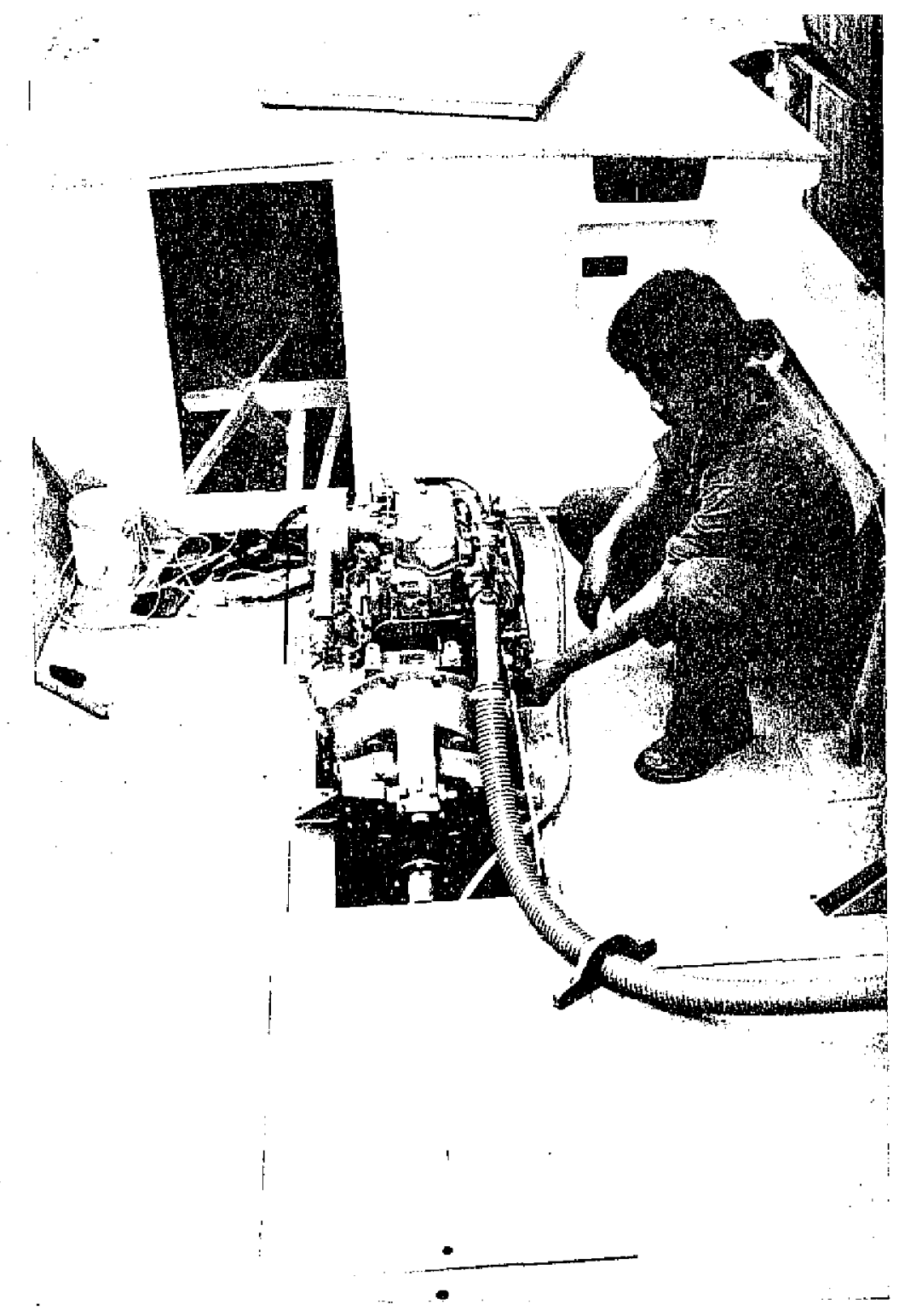

Installing the engine 


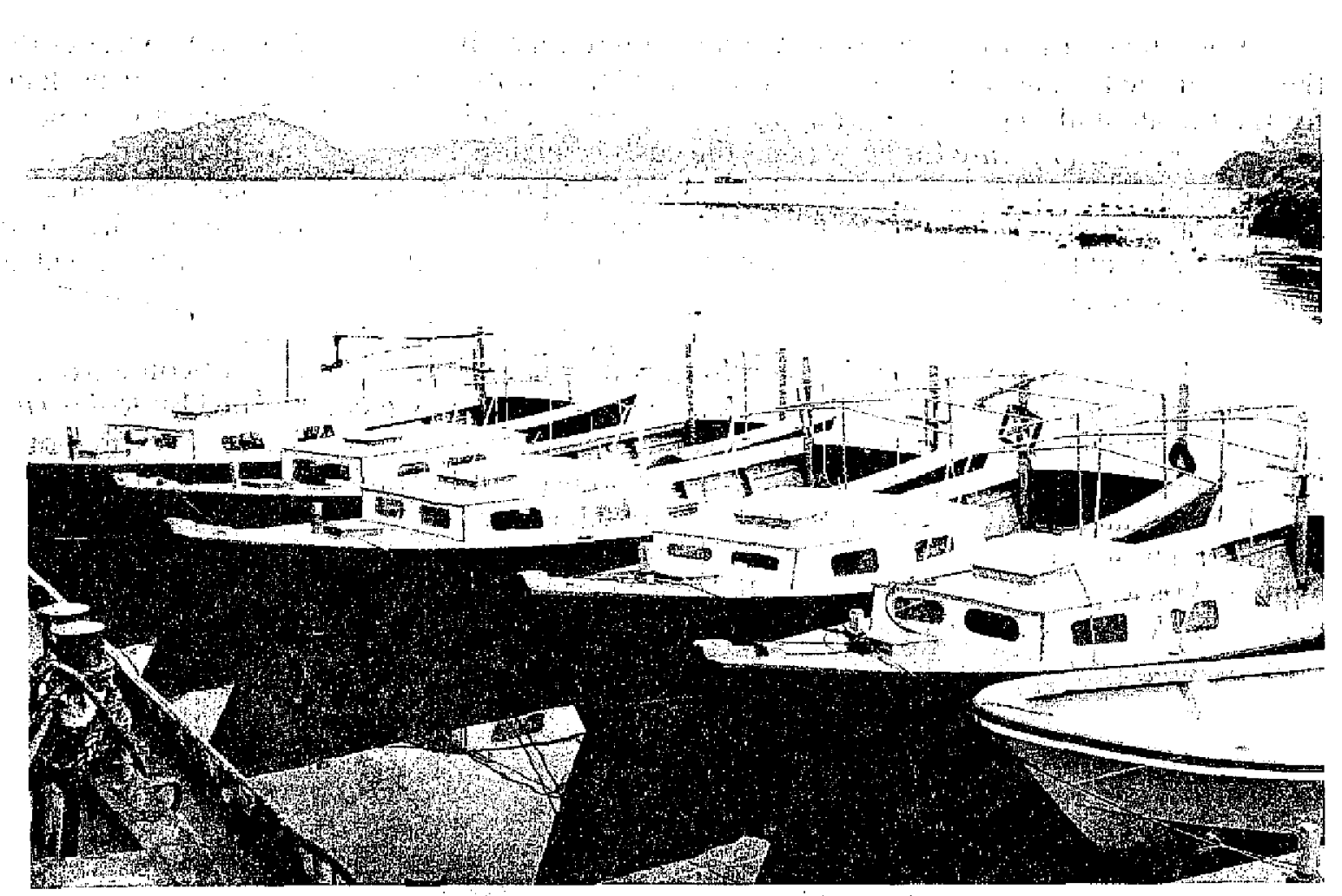

Completed boats awaiting delivery

The response from fishermen has been excellent and there has been keen demand for places on the course. The first group of nine men, from the Central and Northern Divisions, completed the course in June 1981 and are now back in their villages putting what they have learned into practice. All are achieving very good catches and some are in fact paying off more than the minimum required loan repayments. 'Follow-up' surveys are planned for the near future to check that all the boats are being effectively utilised, and a mechanic and carpenter will visit boat-owners where necessary to carry out repairs.

Upgrading village-level fisheries from the subsistence to the artisanal level requires much more than simply the provision of more efficient boats and equipment: the fishermen must be trained to utilise such boats and equipment in the most effective manner and to maintain them properly. The Fiji boat-building and rural training scheme, with its emphasis on 'selfhelp' and practical instruction in boat-building and appropriate fishing techniques, appears to be an excellent way of achieving this. 


\section{DEEPWATER SHRIMPS IN TONGA}

A report entitled 'The deepwater shrimps of Tonga: a preliminary survey near Nuku'alofa' has just been released by the Institute of Marine Resources, University of the South Pacific. The report is one of a series of reports on trapping surveys for deepwater shrimps by the Institute's specialist on deepwater shrimps, Mr Michdel King. (Previously published reports describe the results of surveys in Vanuatu and Western Samoa.) A summary of the report is presented below.

\section{Fishing gear and methods}

Box-shaped traps $70 \times 70 \mathrm{~cm}$ and $40 \mathrm{~cm}$ deep $\left(28^{\prime \prime} \times 28 " \times 16^{\prime \prime}\right)$ were used (Figure 1). The trap frame was welded from steel reinforcing rod and covered with moulded plastic screen with an oval mesh size of 3 to $4 \mathrm{~mm}$ (1/8" approximately) internal diameter. An access gate was hinged to the top of each trap and conical entrances made from the plastic screen were wired into the sides of the traps. One-third of the traps were fitted with two entrance cones on opposite sides, the remainder were fitted with four entrance cones; the inner opening ( 9 to 10 $\mathrm{cm}$ (3 $1 / 2$ " to 4 ") diameter) of the entrance was arranged so that it was not directly opposite the opening on the opposite side.

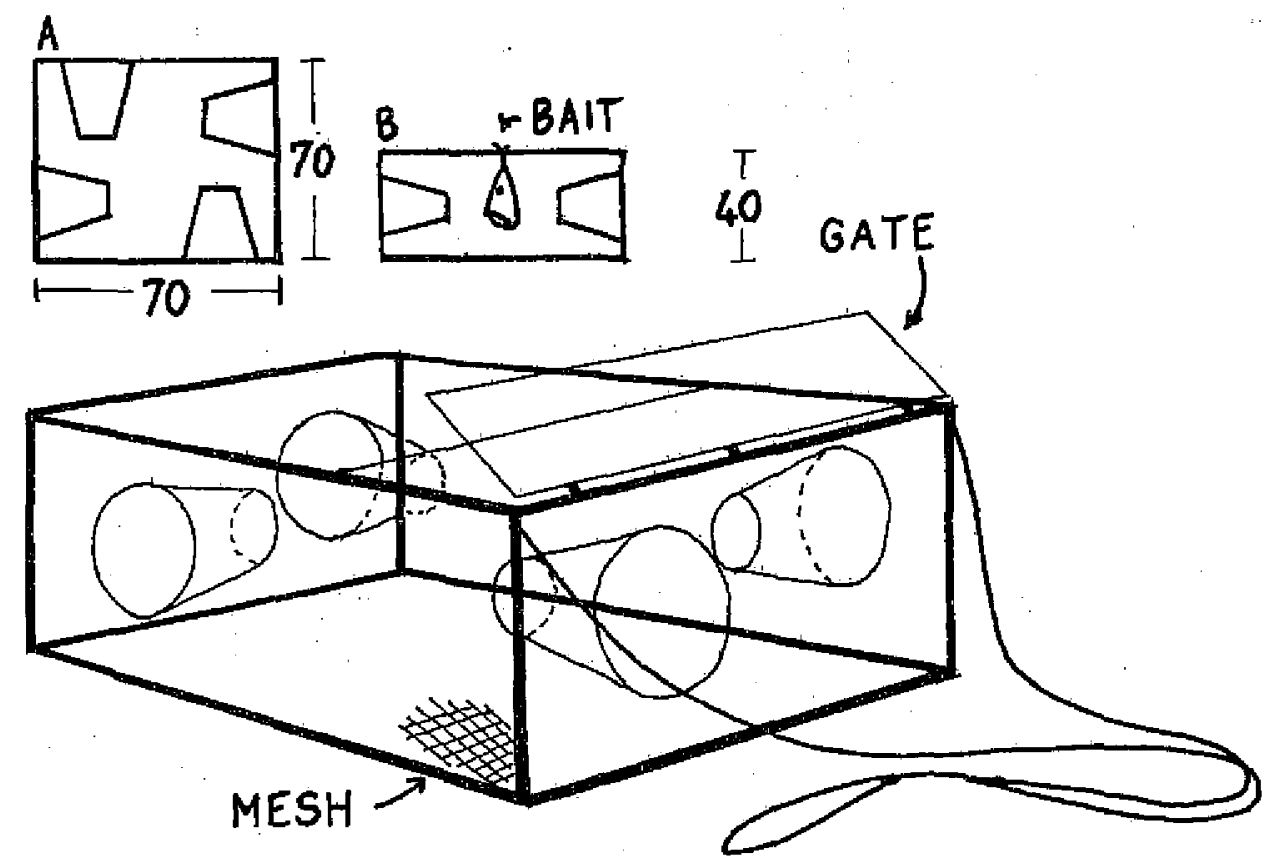

Figure 1: The basic trap design used in the survey. A and $B$ represent the top plan and the side view of the trap respectively. (Dimensions are given in $\mathrm{cm}$.)

The arrangement of the fishing rig is shown in Figure 2. Traps were set in strings of three with a spacing of 15 metres (16 yards) between traps (this relatively wide spacing was used to decrease competitive effects between traps). Each set of three traps included one two-entrance trap positioned between two four-entrance traps.

Traps were baited with a minimum of half a kilo $(1 \mathrm{lb})$ of frozen skipjack, with fresh bait added before each drop.

1. Copies of this report ate available from Mr Michael King, Institute of Marine Resources, University of the South Pacific, Suva, Fiji. 


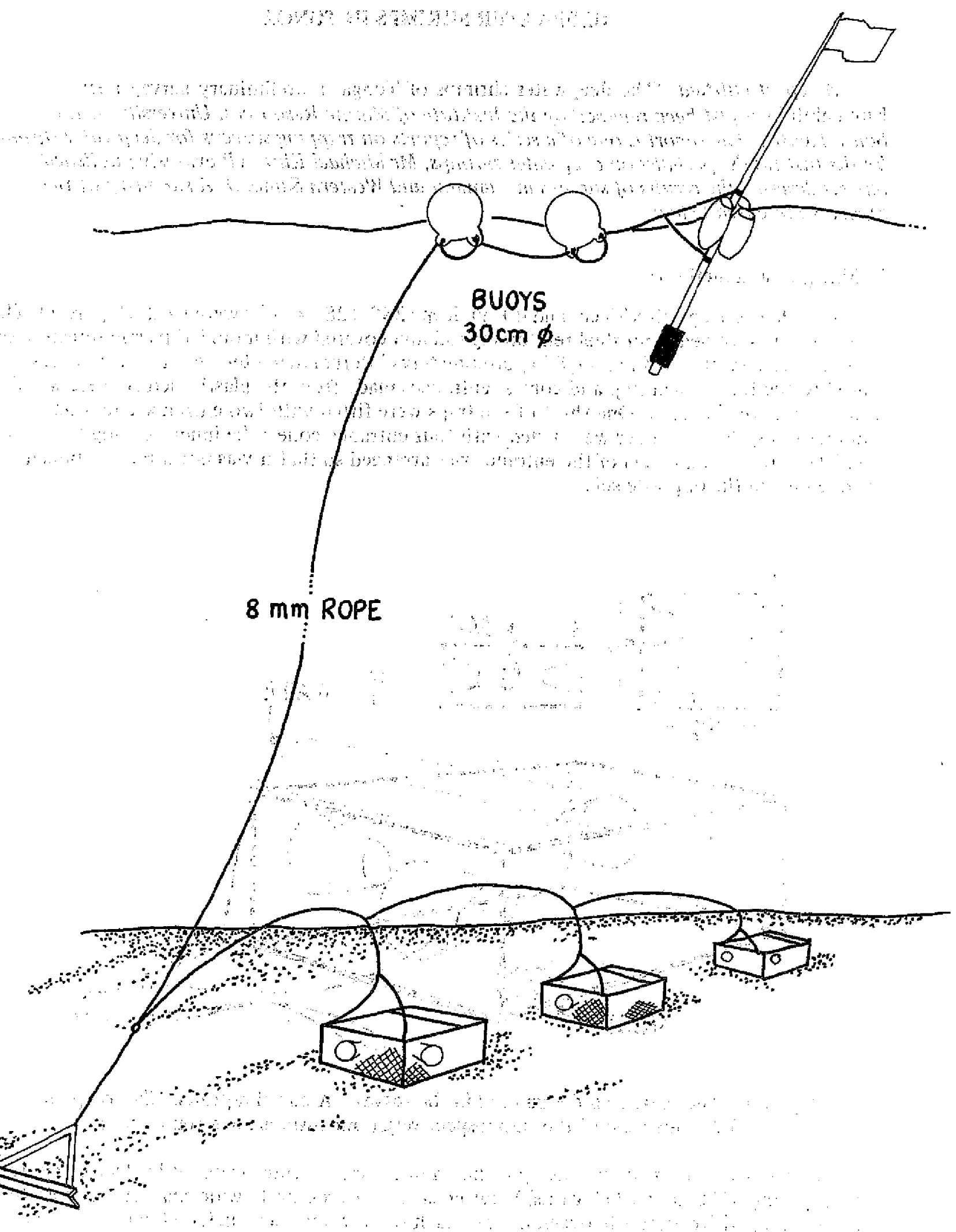

Figure 2: The arrangement of the trap fishing rig used in the survey. The length of drop line used (i.e., between buoys and bottom weight) was equivalent to the depth of the water plus an excess of 25 per cent (minimum). 
A small fibreglass boat powered by a $25 \mathrm{hp}$ outboard was used for the survey. The winch consisted of a $3 \mathrm{hp}$ Briggs and Stratton motor which powered a geared trap hauler via a drive belt. A Skipper model 603 echosounder, fitted with a nartow-beam ferrite tranducer, was used to obtain profiles and measure the depth at each trap drop.

Each string of three traps was generally left in the sea overnight and hauled in, emptied and rebaited before being reset in a new location on the following day.

\section{Results}

\section{Species caught}

A total of eleven species of carid shrimps was caught during the trapping survey. The four most abundant species were Parapandalus serratifrons (pyjama shrimp), Plesionika longirostris (stars and stripes shrimp), Heterocarpus sibogae (mino nylon shrimp) and H. laevigatus (smooth nylon shrimp),

\section{Catch analysis}

Statistical analysis of the total catch (all species combined) showed there was no significant difference in catch rate of shrimp between two-entrance and four-entrance traps, but that total catch varied significantly with depth. A histogram of mean catches (kg per trap) by depth is shown in Figure 3. Mean catch rates of all species combined were highest $(0.6 \mathrm{~kg}$ $(1 \mathrm{lb})$ per trap) in the shallowest $(200-300 \mathrm{~m})$ and deepest $(700-800 \mathrm{~m})$ depth ranges.

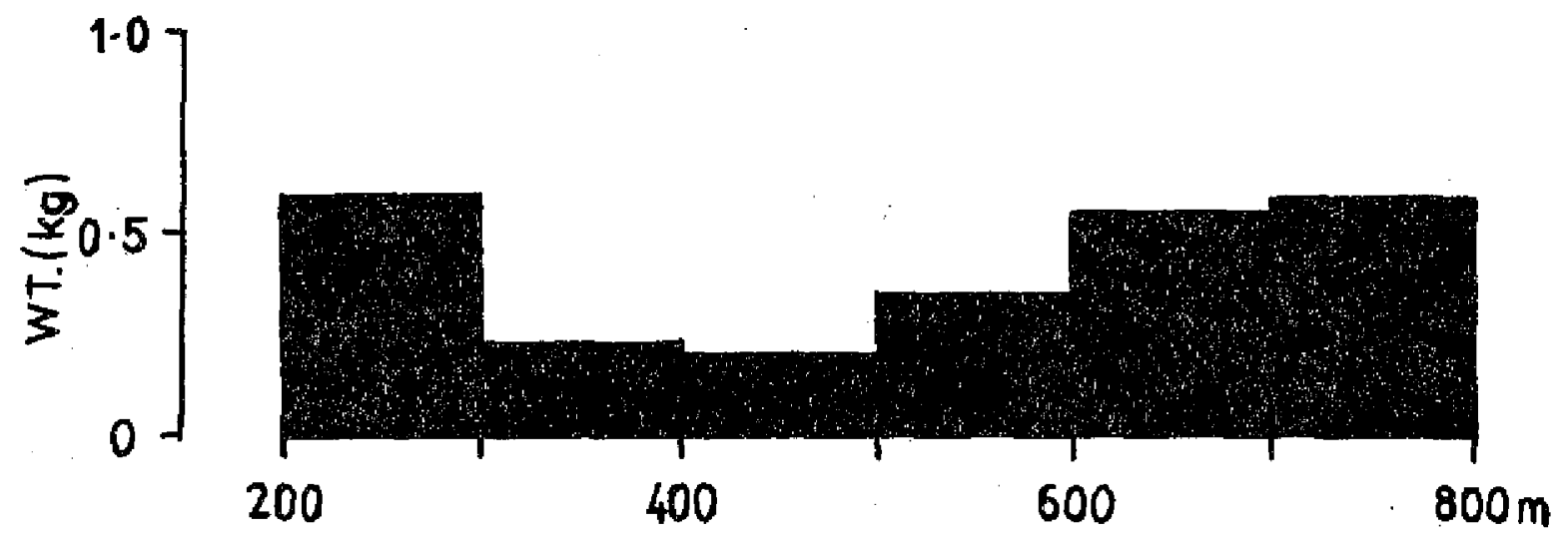

Figure 3: Mean catch $(\mathrm{kg})$ per trap per $100 \mathrm{~m}$ depth range.

\section{Depth distribution of species}

The depth distribution of each species of shrimp was estimated using the mean catch weight per trap as an index of relative abundance; indices for the four major species are shown in Figure 4. It should be noted that these data are from a limited geographical area and collected over a short time scale; the figure may therefore not represent the general distribution throughout Tonga or over a complete seasonal cycle. There was, in general, progression from smaller to larger shrimp species with depth.

\section{Discussion}

Catch rates of shrimp during the survey were lower than those in most other countries. However, the survey off Nuku'alofa was a preliminary one in a limited area and during a limited period of time. During the survey, sediment samples taken at various depths appeared white and clayey with very little organic content; these samples were markedly different from samples taken during surveys in other countries. Refrigerated aquaria studies show that pandalid shrimp appear to feed by picking over the substrate with their pereiopods; consequently, it is likely that some substrate types provide a less suitable environment for shrimps than others. Extended surveys will be necessary to determine whether substrate types are different and shrimp abundances are higher in other areas of Tonga. 


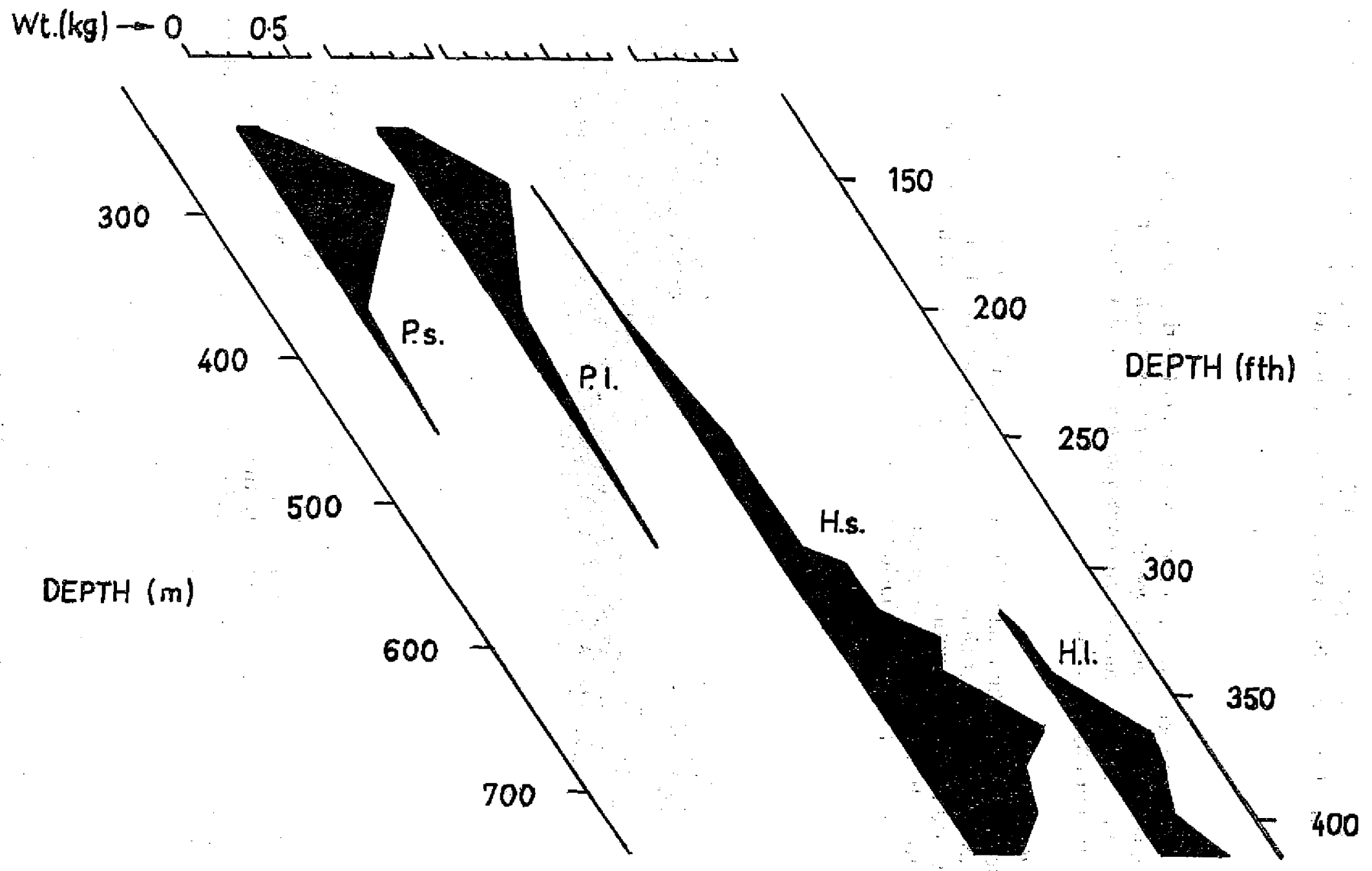

Figure 4: The depth distribution (mean catch per trap) of the four most abundant deepwater shrimps caught during the trapping survey; from left, the species are Parapandalus serratifrons, Plesionika longirostris, Heterocarpus sibogae and $\mathrm{H}$. laevigatus. 
In conclusion, it has beer established that a wide variety of deepwater carid shrimp species are present in Tongan waters. Catch rates made during the preliminarysurvey off Nuku'alofa, although low, were sufficient to encourage carrying out extended surveys in other areas.

\section{Editor's note}

Interested readers may wish to refer to the article 'Deep water shrimp trapping' by James Crossland in the South Pacific Commission Fisheries Newsletter No. 21, August 1980, which reviews the various deep water shrimp trapping trials that have been carried out in the region. 


\section{SEA TURTLES A SHARED RESOURCE OF THE PACIFIC ISLANDS \\ G.H.Balaż \\ National Marine Fisheries Service, $\mathrm{C}$. Box 3830 , Honolulu, Hawaii, 96812}

In Tokelau it is traditional for captured sea turtles to be divided among the entire village through a system known as 'inati' - an equitable method of sharing. Turtles are considered to be sacred fish and therefore may not be taken for personal use. Violations seldom occur, but when they do the punishment consists of public scolding and shame to one's family that can last for generations As a shared resource, turtles make an important contribution to the nutritional and social well-being of the Tokelau people, The quality of atoll life would surely be lessened if turtles cquld no longer be found in Tokelau.

Sea turtles throughout the Pacific are also a shared resource, but not as the result of tradition, or agreements between island people. The shared status of turtles is due instead to the species' own biological characteristics, foremost of which involve regular migrations over great spans of ocean. These voyages are best known to occur between ancestral breeding sites and scattered resident foraging areas. The accompanying map illustrates migrations that have been documented by attaching flipper tags to turtles at several Pacific locations. Relatively few turtles have ever been tagged in the South Pacific Commission area, so the movements shown undoubtedly represent only a small proportion of what actually occurs. Nevertheless, some of the longest sea turtle migrations in the world have been recorded here in the Pacific.

There are two purposes for compiling and publishing this impressive map. First, it serves to graphically demonstrate that sea turtles are indeed a resource shared among widely separated areas. Secondly, it will help to emphasise that some reasonable conservation measures must be undertaken by all those who share in the resource if it is expected to endure. Turtles are extremely vulnerable and easy to catch when they converge at their breeding sites and come ashore to nest. Even at the resident foraging areas turtles can now be captured more efficiently due to the use of outboard motors and modern fishing gear. At some locations this problem has been recognised and conservation practices have been implemented or reinforced. However, a more widespread effort is needed if we are to prevent this valuable but limited resource from eroding further, and possibly being lost to future generations of Pacific people.

\section{SOURCES USED TO ASSEMBLE THIS MIGRATION MAP}

\section{Green Turtles (Chelonia mydas)}

from Scilly (Manuae), French Polynesia

Department of Fisheries. (1979). Tagging and rearing of the green turtle Chelonia mydas conducted in French Polynesia by the Department of Fisheries. Working Paper 4. Joint SPC/NMFS Workshop on Marine Turtles in the Tropical Pacific Islands. Noumea: South Pacific Commission.

\section{from Rangiroa, French Polynesia}

Doumenge, F. (1973). Developinent of the 'Turtle Project' in French Polynesia. The South Pacific Islands Fisheries Newsletter 10: 37-39, Noumea: South Pacific Commission.

McKeown, A. (1977). Marine turtles of the Solomon Islands. Honiara: Fisheries Division, Ministry of Natural Resources. 47 pp.

from Heron Is, and Raine Is., Great Barrier Reef

Limpus, C.J. (1980). The green turtle in eastern Australia. In Management of turtle resources. Research Monograph 1, Townsville: James Cook University of North Queensland.

from French Frigate Shoals, Hawaii

Balazs, G.H. (1979). Synopsis of biological data on the green turtle in the Hawaiian Islands. Working Paper 13, Joint SPC/NMFS Workshop on Marine Turtle in the Tropical Pacific Islands. Noumea: South Pacific Commission. 


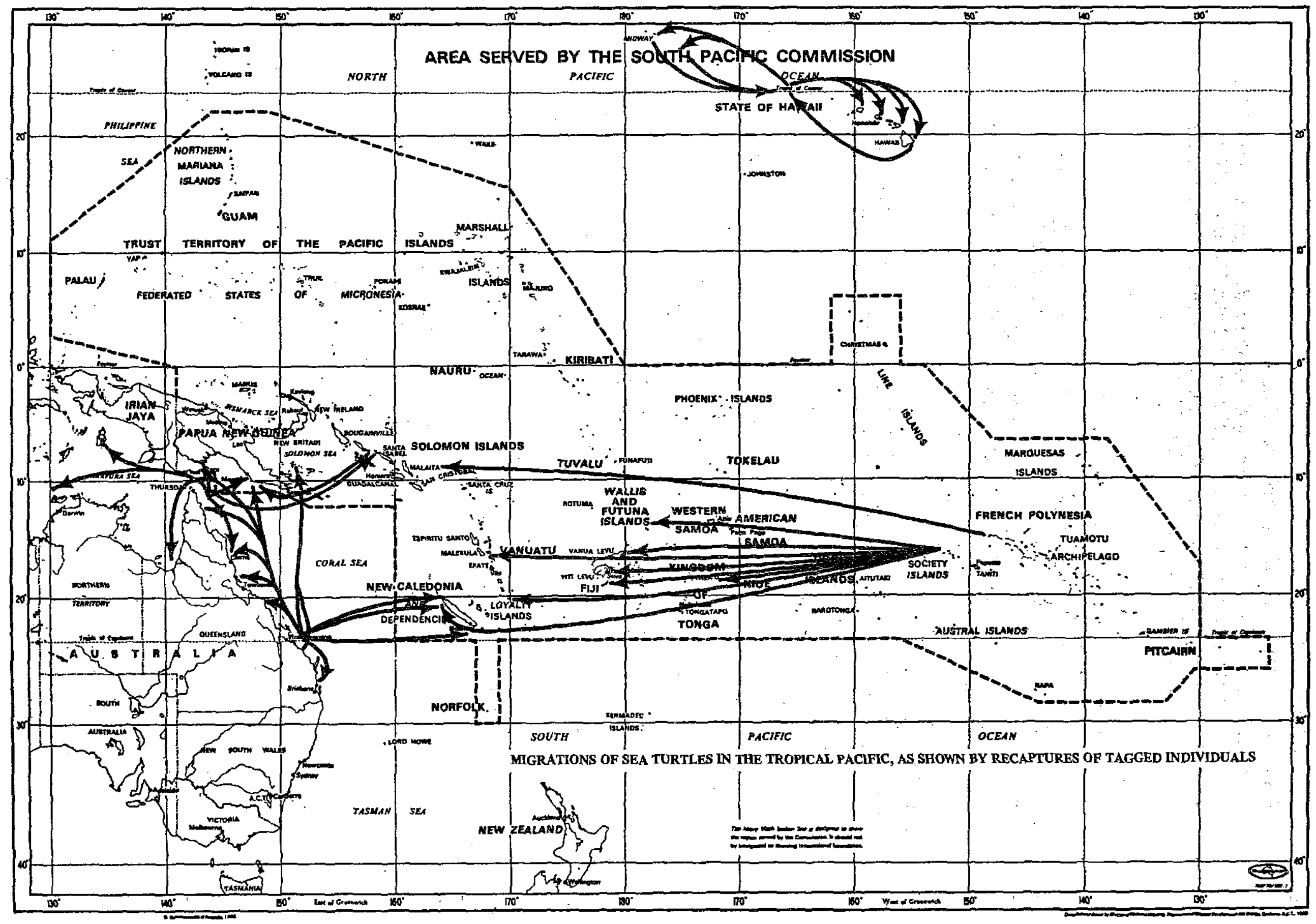


Hawksbills (Eretmochelys imbricata)

from Arnayon Islands (Manning Strait), Solomon Islands

Vaughan, P.W. (1981). Marine turtles: a review of their status and management in the Solomon Islands Honiara: Fisheries Division, Ministry of Natural Resources, $70 \mathrm{pp}$.

Vaughan, P.W., and Spring, S. (1980): Long distance hawksbill recovery. Marine Turtle Newstetter 16. Toronto: University of Ontario.

\section{Loggerheads (Caretta caretta)}

from Heron $I_{s_{i}}$ and Mon Repos (mainland Australia)

Bustard, H.R. (1976). Turtles of coral reefs and coral islands. In Jones, O.A. and Endean, R. (editors), Biology and geology of coral reefs. New York: Academic Press.

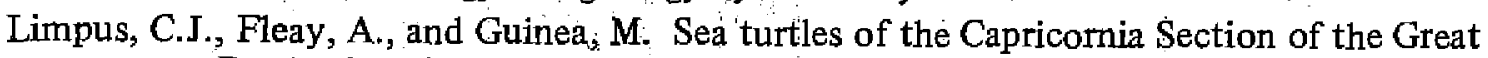
Barrier Reef Marine Park. Proceedings of the Royal Society of Queensland. (In press.)

\section{Related reading}

World Conference on Sea Turtle Conservation. (1980), Sea turtle conservation strategy: abridged version. SPC Fisheries Newsletter 21:8-15. Noumea: South Pacific Commission. 


\section{SHOULD WE RETURN TO SAIL? \\ Oyvind Gulbrandsen's provocative poser and thoughtful reply}

If you asked this question to fishermen in India, eight out of ten would answer 'What do you mean? The shrimp trawlers and a few other boats have got engines, but we have only sails and arm power to move our kattumarams and canoes.'

For India, the question is therefore irrelevant unless we could find a way of catching shrimp on a large scale with sail-powered vessels, and the prospects here do not seem too promising.

Countries which abandoned sail for fishing vessels decades ago, have, however, due to increased cost of fuel, again started looking into the use of sail power. A tuna fishing vessel using sail and engine has recently been launched in France and there is some interest in using sail on the west coast of U.S.A. This is a very small start, but it is a development that was unthinkable only ten years back. The project potential is largely limited to fishing methods like trolling where a constant speed of four to five knots can be achieved by sail. The use of sail for going to the fishing ground and back to port is more an open question. Crew costs are high in developed countries and if the duration of the fishing trip is increased due to the slower speed with sail, the extra crew cost might easily cancel any savings on fuel.

In developing countries where crew costs are low in relation to fuel costs, the prospects of using sail seems a lot brighter. But before being carried away by a vision of white sail against a blue horizon and no noise and fumes from dirty engines, let us look at a specific case, the Sri Lanka 28 -ft boat. Several thousands of this craft have been introduced over the last 20 years. It is presently powered by a $30 \mathrm{hp}$ engine and is utilised for large mesh driftnetting, carrying a crew, gear and fish load of around $800 \mathrm{kgs}$. The boats spend on an average three hours to reach the fishing ground and the same time back, that is, a total of six hours steaming time at full throttle. The increase in the price of fuel over the last years now really starts hurting. What can be done to save on fuel cost?

The fisherman has four options:

1. Travelling at full engine speed $(30 \mathrm{hp})$,

2. Travelling at half engine speed $(15 \mathrm{hp})$,

3. Using sail only,

4. Using sail part of the distance in favourable wind and the engine when the wind is unfavourable.

How do these alternatives compare in fuel saving and extra time saved on the fishing trip? Alternative (4) has, however, so many variables that we have to exclude it in the comparison.

\begin{tabular}{|l|c|c|c|}
\hline & Full power & Half power & Sail only \\
\hline Engine power (hp) & 30 & 15 & 0 \\
Speed (knots) & 7.5 & 6.5 & 4 average \\
Steaming time (hours) & 6 & 7 & 12 \\
Fuel consumption (in litres) & 36 & 21 & 0 \\
Fuel consumption (SRL Rupees) & 216 & 126 & 0 \\
Saving & 0 & 90 & 216 \\
Extra time on the fishing trip (hours) & 0 & 1 & 6 \\
& & & \\
\hline
\end{tabular}

1. This article originally appeared in the September 1981 issue of the Bay of Bengat News. The South Pacific Commission is grateful to the Bay of Bengal News for granting permission to reprint it. 
By going completely back to sail, the fisherman could save 216 rupees $^{1}$ but has to spend an average six hours longer on his fishing trip. Is the saving worth it? I doubt so. A complete return to sail would for a day-trip boat like this be out of the question. If the boat could spend several days on the fishing ground and use ice for keeping the catch fresh, there would be a better case for sail.

The fishermen can use alternative (4) - that is, the use of the sail when the wind is blowing in the right direction and the engine when there is no wind or unfavourable wind. What we have to keep in mind, however, is that although the wind is free; the equipment to catch it - masts, sail, rigging, etc. - costs money and generally clutters up the deck space; especially modern rigging, with terylene sails, aluminium masts and stainless steel wire, is an expensive investment. I personally think that the most immediately beneficial saving with the Sri Lanka 28 -ft boat would be alternative (2) - the boat is grossly ovetpowered with a $30 \mathrm{hp}$ engine. When it was designed by FAO20 years back, an engine of about $15 \mathrm{hp}$ was specified. Since then there has been an escalation in power with a marginal increase in speed. This is similar to a development that has taken place in the fishing industry all over the world due to cheap fuel and the competitiveness among fishermen to go faster than their fellows.

A recent investigation in Norway showed that if the engine power of the Norwegian fishing fleet was cut in half, the average speed would drop only 10 per cent. So, rather than a full-scale return to sail on motorised boats, I believe.in a much more careful use of power. We must first of all use smaller engines and improve on the propellers to get maximum thrust for the power installed. One main exception to the question of reduction in engine power is for trawlers, where there is a relation between the engine power and the catch result. Here again there are large potentials in saving by adopting slow moving, large diameter propellers in nozzles. The governments can play a crucial role in economising on engines and fuel by giving subsidies only for engines up to a specified size related to the boat.

For new construction, the more extensive use of sail in developing countries is of interest because of the possible savings that can be made by installing a low horsepower engine which would be used in calm waters or adverse wind, but the boat would be designed with an efficient but low-cost rig for the use of sail as a main propulsion. An example of this approach is a $28-\mathrm{ft}$ beachboat recently built by $\mathrm{BOBP}^{2}$ in Madras which has a $5 \mathrm{hp}$ air-cooled diesel engine, and a sail area of $27 \mathrm{~m}^{2}$.

For carrying light loads and for fishing methods like handlining, longlining and trolling, requiring small boats, $I$ believe in the development of sailing/rowing craft without engines, based on existing traditional craft like the Oru in Sri Lanka.

I think we will be much nore careful in the future in advocating motorisation as the only way to push production. An engine often doubles the investment cost in a fishing boat. Maybe you could achieve the same production with the same investment by having two sailing craft instead of one motorised craft and thereby provide more jobs and spread benefits a little wider.

I underline the 'maybe' because there are so many variables that have to be considered when introducing new fishing craft and we must not be carried away by a nostalgic "back to the sail movement' forgetting the long hours spent by the crew toiling with rowing oars under a scorching sun on a windless day or trying to reach the shore in winds dead against the direction of travel. But with increasing cost of oil-based energy $y_{z}$ more use of sail power is definitely to be reckoned with in the future.

1. In September 1981, 10.4 rupees were equivalent to one Australian dollar.

2. BOBP: Bay of Bengal Programme. 


\section{RECENT SOUTH PACIFIC COMMISSION FISHERIES PUBLICATIONS}

Anon (1981). Fishing effort and catch by the longline fleets of Japan (1962-1977) and Taiwan (1967-1977) within 200 miles of the countries in the area of the South Pacific Commission/Effort de pêche et prises des palangriers japonais (1962-1977) et Taiwanais (1967-1977) dans la zone des 200-milles des pays desservis par la Commission du Pacifique Sud. South Pacific Commission Skipjack Programme Technical Report 3/ Commission du Pacifique Sud Programme 'bonite' Rapport technique 3.

Anon. (1981). Report of the second skipjack survey and assessment programme workshop to review results from genetic analysis of skipjack blood samples. ${ }^{2}$ South Pacific Commission Skipjack Programme Technical Report 6.

Ellway, C.P. and Kearney, R.E. (1981). Changes in the Fijian baitfishery 1974-1980.1 South Pacific Commission Skipjack Programme Technical Report 5.

Kearney, R:E. (1981). Skipjack survey and assessment programme: Annual report for the year ending 31 December 1980. ${ }^{2}$ South Pacific Commission, Noumea. 16 pp.

Kearney, R.E. and Rivkin M.L. (1981). An examination of the feasibility of baitfish culture for skipjack pole-and-line fishing in the South Pacific Commission area'. South Pacific Commission Skipjack Programme Technical Report 4. 